\title{
Moving on up: The impact of income mobility on antisocial behaviour
}

\author{
Lata Gangadharan ${ }^{1}$, Philip J. Grossman ${ }^{2}$ and Joe Vecci ${ }^{3}$
}

\begin{abstract}
:
While the causes for upward income mobility have received considerable attention, the behavioural impact of the prospect of mobility has been largely overlooked. Using a survey and experiment, we investigate if the prospect of mobility influences antisocial behaviour. In our experiment, low- and high-income participants make decisions in an investment game in which, at a cost, they can reduce others' payoff. A unique feature of the experiment is that lowincome participants can move up the income distribution, via chance or effort. Results show that immobility fuels antisocial behaviour, in particular towards high-income participants.
\end{abstract}

Keywords: Income inequality, Prospect of upward mobility, Antisocial behaviour, Experiment, Survey.

JEL Codes: C91, D003, D6

\footnotetext{
${ }^{1}$ Monash University, lata.Gangadharan@monash.edu

2 Monash University and Rasmuson Chair, University of Alaska, Anchorage. philip.Grossman@monash.edu

3 Gothenburg Univeristy. joseph.Vecci@gu.se
}

Acknowledgements: Gangadharan and Grossman acknowledge financial support from the Australian Research Council (Discovery Project DP1411151. Vecci acknowledges support from the Swedish Research Council (Project no. 348-2014-4030). We are grateful to participants at the European and North American Economic Association Meetings. 


\section{Moving on up: The impact of income mobility on antisocial behaviour}

\section{Introduction}

A defining feature of democratic capitalist societies is disparity in the distribution of income and wealth. Recent reports indicate that income inequality in OECD countries has reached its highest level in decades (OECD 2011). The top $10 \%$ of income earners now receive nine times that received by the bottom $10 \%$ of earners. ${ }^{4}$ This disparity in income is likely to grow. Chetty et al. (2014a), for example, find that a critical determinant of a child's future income is her family's current income relative to the income of other families. Further, absolute income mobility (i.e., the fraction of children who earn more than their parents) has declined drastically over time, from approximately $90 \%$ for children born in 1940 to $50 \%$ for children born in the 1980s (Chetty et al., 2017).

What has puzzled many about this disparity in economic fortunes is the fact that in democratic nations, the majority with below median wealth, however envious they may be of their fellow citizens with above median wealth, have not used their numbers to enact tax and transfer policies that redistribute wealth to themselves. Benabou and Ok (2001) offer their "prospect of upward mobility (POUM)" hypothesis as one possible (or partial) explanation. The POUM hypothesis has as its premise the idea that those who are poorer than average expect that either they, themselves, or their children will succeed economically and become richer than average. The faith that, through dedication and hard work, an individual can climb the ladder of success is a central feature of the "American dream" (Samuel 2012). Their envy, rather than being directed at

\footnotetext{
${ }^{4}$ There is similar evidence of growing disparity in net wealth. In 2013 in the USA, for example, the top $10 \%$ of families controlled $76 \%$ of all family wealth, while those in the bottom $50 \%$ controlled 1\% (Congressional Budget Office 2016). On average, in 2012 in the OECD countries, the top $10 \%$ held approximately $50 \%$ of all wealth (OECD 2016).
} 
taking what others have, compels them to increase their productivity, try to be more creative, and do their utmost to become one of the rich. ${ }^{5}$ Benabou and Ok and other researchers (Roemer 1998; Putterman 1997) argue that it is the belief in POUM that explains the relatively low support for high tax rates and redistributive public policies. Studies by Alesina et al. (2001) and Cojocaru (2014) offer empirical support for the POUM hypothesis.

Faith in POUM may affect people's behaviour in other ways. In the same way POUM suppresses support for redistributive policies, POUM may also suppress antisocial behaviour. If upward mobility is possible (or believed possible), an aspirant may not feel the need to behave antisocially. If, however, there is little or no prospect of upward mobility (what some term an inequality of opportunity), people frustrated with their inability to improve their lot may resort to antisocial behaviour. This may be because limited economic opportunities are perceived as unjust and unfair (Brunori et al., 2013; Cappelen et al., 2013). ${ }^{6}$ Despite these behavioural implications and the recent downward trend in mobility, whether POUM influences antisocial behaviour is still an open question.

This study is the first attempt to investigate experimentally if POUM influences antisocial behaviour. ${ }^{7}$ In particular, we focus on three research questions. First, does POUM discourage antisocial behaviour? Second, what is the impact of POUM on antisocial behaviour under different initial income class

\footnotetext{
${ }^{5}$ The existence of these two qualitatively different forms of envy (i.e., destructive and constructive envy) has been documented across cultures, even though some cultures have distinct and specific words to distinguish among these two types of envy (i.e., the Netherlands, Poland) while others do not (i.e., the United States, Spain) (van de Ven et al., 2009).

${ }^{6}$ Cappelen et al. (2013) use a laboratory experiment to study fairness views about risk taking. The authors vary the equality of opportunity and find that most subjects have preferences for ex-ante opportunities but also that most favour some redistribution ex post.

${ }^{7}$ Despite significant research measuring mobility, there is little research investigating the impacts of mobility on behaviour. In an interesting recent paper, Alesina et al. (2017) use crosscountry data on perceptions to understand the relationship between perceptions of intergenerational mobility, views about fairness, and preferences for redistribution. The authors find a significant correlation between pessimism and optimism about social mobility and policy preferences. Across all countries, more pessimistic respondents favour more generous redistributive policies. While their study focuses on attitudes and perceptions, it is silent about the impact of mobility on actual behaviour.
} 
assignments (based on effort or luck)? Finally, does the nature of mobility, i.e., whether one moves up the income distribution through effort or luck, influence antisocial behaviour?

To address these questions, we design and conduct a survey as well as a unique laboratory experiment. The survey uses vignettes and provides suggestive evidence that POUM may reduce antisocial behaviour. Approximately $80 \%$ of the respondents believe that a lack of mobility will increase antisocial behaviour. While our respondents believe that the method of initial income allocation will not influence rates of antisocial behaviour, they do believe that when mobility occurs through effort, antisocial behaviour will be less relative to when mobility occurs through luck.

While the survey approach is useful to gauge general attitudes about mobility and help develop research hypotheses, it is less useful to make causal inferences about the impact of mobility on antisocial behaviour. We therefore complement the survey with a laboratory experiment. The laboratory experiment consists of a two-stage, multiperiod saving/investment game. In the first stage, participants either invest or save their endowments. The second stage introduces an additional option: participants can reduce the earnings of another participant at a personal cost. This stage is designed to observe the existence, intensity, and pattern of participants' antisocial behaviour. It is important to document and understand this kind of financially vindictive behaviour, as it can be potentially harmful to innovation and the functioning of competitive markets, and would likely impede economic growth.

To understand the impact of the prospect of mobility on behaviour, we design treatments that vary along two dimensions: how initial income is assigned and how mobility may be achieved. Initially, participants are allocated to the high-income group or the low-income group. High (low) income participants have larger (smaller) initial endowments and higher (lower) rates of returns to their investments. In half the treatments, luck determines the initial income allocation; in the other half, performance in a real effort task determines 
the allocation. Treatments also differ along a second dimension; whether mobility is possible and how it is attained. In two treatments, there is no possibility of mobility; in the other treatments, low-income subjects have an opportunity (via luck or effort) to change their income group.

Consistent with the initial survey evidence, we find significantly lower rates of antisocial behaviour in the mobility treatments than in the immobility treatments. High-income subjects benefit most from the prospect of mobility; they encounter antisocial behaviour 8 percentage points less often relative to the immobility setting. When mobility is not possible, there is little difference in antisocial behaviour regardless of how income is initially assigned. However, when mobility is possible, subjects with an initial income assigned through luck make antisocial decisions at half the rate of those assigned via effort. The combination of mobility and initial income mechanism thus appears to be important. When we investigate the different mobility mechanisms, we observe that mobility via effort has lower rates of antisocial behaviour relative to mobility via luck, but this difference is not statistically significant. These results show that POUM itself, independently of how it is achieved, plays a pivotal role in reducing antisocial behaviour. Overall, we find that the antisocial behaviour triggered by the lack of mobility options creates significant welfare costs. The welfare costs from antisocial behaviour in our immobility treatments are twice as large as in the mobility treatments.

Our study contributes to the literature in several ways. First, our paper provides insights on how antisocial behaviour responds to POUM. This in contrast to a large body of research on mobility that focuses on measuring rates of absolute mobility or the determinants of mobility (Chadwick and Solon 2002; Solon 2002; Lee and Solon 2009; Chetty et al., 2014a; Chetty et al., 2014b; Chetty et al., 2017). Another strand of this research uses cross-country data on perceptions to understand the relationship between perceptions of intergenerational mobility, views about fairness, and preferences for redistribution (Alesina et al., 2017). Our focus on antisocial behavior, apart from 
being novel, is motivated by its ubiquitous nature, as it is prevalent across time and cultures. Importantly, understanding the relationship between POUM and antisocial behavior can be critical to reduce its impact on social welfare. Our paper is a first step in this direction.

Second, we use a stylized laboratory experiment specifically designed to understand the relationship between POUM and antisocial behaviour. Using other empirical approaches is challenging for at least two reasons. First, it is difficult to assign mobility randomly; each individual brings his/her own experiences and opinion regarding the prospect of mobility, thus making it difficult to tease out the impact of mobility separately from these experiences. Second, the existing research utilises datasets that do not contain behavioural measures. The experimental approach circumvents these problems by inducing mobility in the lab and observing the behavioural response. To the best of our knowledge, this is therefore the first study to establish a causal link between POUM and antisocial behaviour. Finally, this research also contributes to the literature on mobility by identifying possible mechanisms through which POUM may affect behaviour. In particular, our paper is the first to examine whether the POUM through effort or luck differentially influences antisocial behaviour. This is particularly important as research has identified that behaviour differs markedly when outcomes are based on luck relative to effort (Cappelen et al, 2013).

\section{Research Strategy}

\subsection{Experimental Design}

The experiment comprises two decision-making stages and a postexperiment survey to collect demographics such as gender, age, and study major. At the start of a stage, subjects receive hard copies of instructions that the experimenter reads aloud to establish common knowledge among all subjects. The instructions with payoff information are also provided through ztree (Fischbacher 2007) which subjects can read at their own pace. 
In both stages, subjects interact in a fixed group of $10 .{ }^{8}$ Five subjects are assigned to the high-income (HI) group and five are assigned to the low-income (LI) group. HI (LI) subjects are known as Type A (B) subjects during the experiment. Allocation to income class is explained in Section 2.2 below.

In stage 1 , all subjects take part in an investment task for 10 periods. HI types have per period endowments twice that of the LI types (60 versus 30 cents, respectively) and higher expected returns from investing (25\% versus $20 \%$, respectively). In each period, subjects choose to either save or invest their endowments. Investment has a 50\% probability of success. If the investment is successful, HI and LI types receive 120 cents and 52 cents, respectively. If the investment is not successful, HI and LI types receive 30 and 20 cents, respectively. At the end of each period, earnings of all the subjects are displayed on the screen, along with their types. This stage creates income differences between the two income groups and helps reinforce them over the periods.

Subjects begin stage 2 with their original income class designation. In stage 2 , subjects participate in 20 periods identical to stage 1 , except subjects now also have the option to attack (reduce the earnings of) any one person in their group at a cost to themselves. In each period of stage 2 , subjects make two decisions. The first is whether they want to attack a specific subject or no one. They may only attack one subject per period. It costs the perpetrator 5 cents to attack and the victim's earnings decrease by 20 cents. The earnings of a victim attacked by more than one subject in the same period decrease by only 20 cents. ${ }^{9}$ When considering whether to attack, subjects view a table reporting each subject's previous period earnings, each subject's cumulative earnings, and own payoff consequences for any action taken. The second decision is whether to save or invest the remaining endowment.

\footnotetext{
${ }^{8}$ All but two sessions contained one 10-person group; the remaining two sessions contained two 10-person groups.

${ }^{9}$ Uncertainty that an attack will have the intended effect may deter some players from attacking. If so, our measure of antisocial behaviour may represent a lower bound.
} 
Stage 2 allows us to examine whether subjects engage in antisocial behaviour and if that influences their investment decisions. As in stage 1, at the end of each stage 2 period, subjects view a table reporting all subjects' previous period earnings and all subjects' cumulative earnings. Whether a subject was attacked or was the perpetrator of an attack is not revealed to the other group members. The instructions are presented in Appendix A3.

\subsection{Treatments}

As POUM is a complex phenomenon, we designed the experiment so as to capture a number of key components of mobility; in particular, we focus on how initial income is assigned and how mobility is achieved (via luck or effort). We vary these experimentally to determine their impact on antisocial behaviour. To this end, we implement a 2 (initial income class assignment) x 3 (mobility) design, with six between-subject treatments. The treatments are reported as " $a / b$ " where ' $a$ ' represents the method of initial endowment assignment and ' $b$ ' the mobility mechanism.

In two treatments (Luck/Immobility and Effort/Immobility), subjects retain their stage 1 income class through all 20 periods of stage 2 (see Table 1 for details of all treatments); thus mobility is not possible. In Luck/Immobility, luck determines the initial income assignment (random assignment), while in Effort/Immobility it is determined by effort (in a counting zeros task), with the top (bottom) five performers assigned the HI (LI) class. ${ }^{10}$ In the Effort/Immobility treatment, subjects are not informed of the number of problems they solved or solved correctly. ${ }^{11}$

These two treatments represent situations in which mobility is not possible, and initial allocation determines future outcomes. These treatments act as controls and allow us to compare situations of mobility relative to immobility. More specifically, our Luck/Immobility treatment is representative of the fact

\footnotetext{
${ }^{10}$ Subjects had 200 seconds in which to complete as many strings of zeros as possible.

${ }^{11} \mathrm{We}$ wanted subjects to focus on differences between income classes, not on differences within income classes. Reporting scores may have enhanced within-class rivalries.
} 
that one cannot choose his/her parents. We include the Effort/Immobility treatment more for completeness than as representative of any particular state of the world.

There are four mobility treatments (Luck/Luck, Luck/Effort, Effort/Effort, and Effort/Luck). In these treatments, after the $10^{\text {th }}$ period of stage 2, LI types have the opportunity to change their income class from LI to HI. In particular, in the Luck/Effort and Effort/Effort treatments, LI types can choose to pay 200 cents to compete in a counting zeros task for the opportunity to change their income class. To change income class, a subject must correctly complete 18 or more problems in the allotted 200 seconds. This requirement is based on the performance of the top $20 \%$ of performers in the initial income class assignment task in the Effort/Immobility treatment. Successful subjects retain their 200 cents, earn a $20 \%$ return on their gamble, and acquire the HI class for the remaining 10 periods. Unsuccessful subjects lose their 200 cents and retain their LI class for the remaining 10 periods.

In the Luck/Luck and Effort/Luck treatments, LI types can choose to gamble 200 cents for the opportunity to change income class. If a subject chooses to gamble, she selects one of 10 cards. There are two $\mathrm{W}$ cards and eight $\mathrm{X}$ cards. If the subject selects a W card, the subject retains her 200 cents, earns a $20 \%$ return on her gamble, and acquires the HI class for the remaining 10 periods. The $20 \%$ probability of success (two out of ten cards) equals the percentage of LI types in the Effort/Effort and Luck/Effort treatments who attempted to change income group and were successful. ${ }^{12}$ If the subject selects an $\mathrm{X}$ card, the subject loses the 200 cents and retains the LI class for the remaining 10 periods. The Effort mobility treatments are representative of societies where upward mobility may be achieved by hard work, while our Luck mobility treatments are

\footnotetext{
${ }^{12}$ To keep the probability of success the same across treatments, we conducted all Luck/Effort and Effort/Effort sessions prior to the Luck/Luck and Effort/Luck sessions.
} 
representative of the fact that upward mobility can be random (i.e., winning the lottery, discovering oil on one's land, or inheritance). ${ }^{13}$

HI types and those LI types who choose not to attempt the income class change predict how many LI types they believe will attempt to change their income class. ${ }^{14}$ A correct prediction earns a subject $\$ 0.50$.

Recruitment of subjects took place via ORSEE (Greiner 2015) and all sessions were conducted at Monash University's MonLEE lab. In total, 370 subjects participated in 35 sessions. All subjects were inexperienced in the sense that they had never previously participated in an experiment with features like the one reported in this paper. Subject earnings averaged AUD\$25.83, with an interquartile range of $\$ 17.19$ to $\$ 36.60$. Sessions lasted about 90 minutes, including the time taken for instructions and payment distribution. ${ }^{15}$

\section{Inequality, Mobility, and Antisocial Behaviour: Development of}

\section{Hypotheses}

In this section, we outline our predictions and discuss situations in which we would expect to see a decrease in antisocial behaviour. As empirical research on the impact of POUM on antisocial behaviour is still in its infancy, we conduct an online survey to investigate perceptions about immobility and its effect on antisocial behaviour. We discuss the results of this survey and use these along with our intuitive framework to develop hypotheses.

If we start by initially ignoring mobility and the associated treatments and focus on the basic game, we expect individuals who are only interested in

\footnotetext{
${ }^{13}$ It is useful to note that while the luck mechanism to assign initial income and the luck mechanism to move up the income distribution are based on a random allocation, in the latter mechanism, subjects specifically play a card game.

${ }^{14} \mathrm{HI}$ types predict how many out of five; LI types predict how many out of four. This prediction task ensures that all subjects are actively engaged on their screens, thus making subject type and the decision to aim to change income class anonymous.

${ }^{15}$ The experiment also has a third stage, in which all subjects take part in a one-shot, 10-person, voluntary contribution mechanism game. All subjects are endowed with $\$ 5$ and divide their endowments between their own Individual Account and a Group Account. Allocations to the Group Account are doubled and every member of the group receives an equal share, regardless whether they allocated to it or not. Subjects' earnings from this stage are added to their total earnings from stages 1 and 2 .
} 
maximizing their individual payoff to disregard the information they receive about the earnings of others and choose not to spend money to reduce others' earnings. Theoretically, therefore, we should not observe antisocial behaviour in this game.

Evidence from experiments, however, indicates that individuals are often willing to use their own money to undertake destructive actions that reduce others' earnings even in situations where there are no obvious benefits for themselves or other people (Abbink et al., 2009 and 2011). We expect therefore to observe individuals attacking others in our setting. Further, when individuals have different income levels, previous evidence has shown that antisocial behaviour is usually targeted towards those who are richer or have higher status (Dawes et al., 2007; Gino and Pierce 2009 a,b; Grossman et al., 2016).

The central research question addressed by our study is whether opportunities for income mobility can change the frequency or the pattern of antisocial behaviour. The possibility of earning more, or moving up the income distribution, could have several implications for antisocial behaviour. Previous research (for example, Rabin 1993; Fehr and Schmidt 1999; Cappelen et al., 2013) has shown that motives for fairness can impact behaviour in the presence of inequality and that individuals are willing to give up some material benefit to improve the equitability of outcomes (Almås et al., 2010).

In our context, the potential to move up the income distribution may be considered a fairer environment relative to immobility as POUM reduces the inequality in opportunities, leading to less frustration and consequently lower antisocial behaviour by LI types. ${ }^{16}$ Perceived fairness may also affect the social appropriateness of behaving antisocially; in the (fairer) mobility treatment, it may be less socially appropriate to behave antisocially relative to the (less fair) immobile environment. Alternatively, mobility may focus the attention and the resources of LI types towards becoming high income and hence decrease their

\footnotetext{
${ }^{16}$ Environments perceived to be more equitable often display more prosocial behaviour (Fehr and Schmidt 1999).
} 
propensity for antisocial behaviour. Taken together, these explanations suggest that POUM will decrease antisocial behaviour.

The impact of POUM on antisocial behaviour mainly relates to the LI types. In our design, HI types are unaffected by the opportunity for income mobility. They do not experience much conflict because they cannot be displaced from their income class. The movement of LI types into the HI class is not very likely to change relative rankings of HI types and may not therefore influence their antisocial behaviour.

Our design also allows us to observe how the mechanism assigning initial income affects antisocial behaviour by LI types. With initial income assigned randomly, LI types may perceive themselves to be disadvantaged but perceive the mechanism as procedurally fair. On the other hand, effort-based income assignment may also be considered procedurally fair.

The mobility mechanism can also influence behaviour. With luck-based rather than effort-based mobility, it is plausible that LI types will exhibit a higher probability of attacking as they lack control over the movement to HI, which may lead to more resentment and more antisocial behaviour. ${ }^{17} \mathrm{~A}$ summary of the outlined conjectures is shown in Table 2.

\subsection{Survey}

Since research on the impact of POUM on antisocial behaviour is still scarce, an important first step is to identify perceptions about the relationship between mobility and antisocial behaviour. To this end, we design and implement a survey using Amazon's Mturk to investigate empirically perceptions about immobility and its effects on antisocial behaviour. The survey consists of 237 participants. It took 7 minutes on average, with participants paid $\$ 1.45$ USD for successfully completing the survey. To ensure the survey's validity we: (i) initially screen subjects to ensure they reside in the United States and are above the age of 18 years; (ii) implement three attention checks at

\footnotetext{
${ }^{17}$ Fox and Spector (1999) show that the locus of control (a measure of one's sense of control over his/her life) is directly correlated with antisocial behaviour.
} 
different points in the survey to discourage respondents from randomly selecting responses; ${ }^{18}$ and (iii) prevent respondents from quickly clicking through the survey without reading questions, as they can move to the next question only after 12 seconds.

The survey commences by eliciting respondents' general attitudes towards the POUM and its impact on behaviour. Specifically, we ask them to consider the following vignette:

- Suppose that there is limited income mobility in your country. In this case, do you believe that limited income mobility could impact behavior?

Possible responses for this question and the following questions are "increase prosocial behavior," "not change behavior," or "increase antisocial behavior."

To study attitudes towards POUM, conditioning on an individual's initial income allocation, we present two further vignettes. All five vignettes are in Appendix A2.

In the first, we ask respondents to think of a situation in which the assignment of initial income is via effort/hard work. We enquire whether in this context limited mobility could influence behaviour. ${ }^{19}$ The second vignette is identical but for initial income assigned via luck/chance. By comparing responses to these two vignettes, we can explore whether the method of initial income allocation differentially affects antisocial behaviour.

Finally, to investigate the impact of POUM and the different mobility mechanisms, we posed two new vignettes (one with mobility via effort/hard work and one with mobility via luck/chance). We ask whether mobility by effort/hard work (luck/chance) could affect antisocial behaviour relative to a setting in which income mobility is limited. We compare these responses to

\footnotetext{
${ }^{18}$ For instance, directly after eliciting opinions about income mobility, we tell respondents: "Thank you for answering the prior questions. You will now be asked a number of attitude and demographic questions. To proceed, please select 'strongly disagree'." Subjects that failed to answer with strongly disagree where removed from the survey without payment. In total 7 respondents failed at least one attention check.

19 These questions are comparable to the Effort/Immobility and Luck/Immobility treatments.
} 
understand whether the different mobility mechanisms differentially influence antisocial behaviour. ${ }^{20}$

We first expose all respondents to the first vignette on mobility, while the ordering of the latter four vignettes is random. We also asked several related open-ended questions to provide empirical evidence for the conjectures highlighted in Section 3. In particular, after eliciting opinions about actions in each respective setting, we ask respondents why they believe the setting will affect behaviour. Analyzing responses to these questions, we can identify if respondents mention different motivations for antisocial behaviour. Subjects also complete a demographic survey.

\subsection{Survey findings}

The survey findings and t-test statistics of the difference in responses across vignettes are summarized in Table 3. As this research is about antisocial behaviour, we mainly discuss responses relating to this; however, for transparency we report all responses in Table 3 . The results suggest that limited opportunities for mobility influence antisocial behaviour. More specifically, $78 \%$ of respondents believe that a general lack of income mobility will increase antisocial behaviour (see Table 3, row 1, column 1). This falls to $65 \%$ when initial income is based on luck (row 1, column 2) and 58\% when initial income is based on effort (row 1, column 3). The difference between luck and effort is statistically insignificant, $\mathrm{p}$-value $=0.13$. This suggests that the attitudes about the prevalence of antisocial behaviour do not differ based on the initial income assignment. We also find that only $8 \%$ of respondents believe that the potential to move up the income distribution through effort will increase antisocial behaviour (row 4 , column 2 ); this is relative to $26 \%$ when mobility is through

\footnotetext{
${ }^{20}$ For simplicity, these two questions do not reference initial income allocation. Therefore, comparing these two questions is similar to holding initial income assignment constant and comparing the effort and luck mobility treatments.
} 
luck (row 4, column 3). This difference is statistically significant, p-value = $0.00 .^{21}$

To investigate factors underlying the relationship between POUM and antisocial behaviour further, we elicited open-ended responses from the participants. From our earlier discussion, we expect fairness, and related beliefs, to be an important explanatory factor. We find that approximately $12 \%$ of respondents used the explicit words fair or unfair when describing why they believe immobility may increase antisocial behaviour. ${ }^{22}$ For instance, one subject responded: “... people would feel frustrated at the unfairness of a system that doesn't permit income mobility and could become aggressive because of that." When we expand the key words to describe negative affect states such as frustration, jealously, animosity, antisocial and anger, we find that $62 \%$ of respondents used these words when describing why immobility may increase antisocial behaviour. $^{23}$

These responses suggest that a lack of mobility is considered unfair and unequal and a lack of mobility may make people frustrated and angry. This may be particularly problematic if increases in frustration and anger increase the social acceptability of acting antisocially. To test empirically the latter channel, we ask two further questions about the social appropriateness of acting antisocially when income mobility is low. In particular, we ask:

\footnotetext{
${ }^{21}$ Table 3 also reports the potential for mobility to increase prosocial or not change behaviour. Only a small percentage (10-14\%) of our respondents believe that immobility, irrespective of whether initial income exists via luck or effort, will increase prosocial behaviour. In contrast, close to $72 \%$ (34\%) of respondents believe that, relative to a setting without mobility, mobility through effort (luck) will increase prosocial behaviour ( $\mathrm{p}$-value $=0.00$ ). Approximately $12 \%$ of our respondents believe that immobility will not change behaviour. For initial income allocations by luck (effort), $22 \%(28 \%)$ indicated this would not change behaviour ( $\mathrm{p}$-value $=$ $0.22)$. Twice as many respondents $(40 \%$ versus $20 \%)$ believe that mobility through luck will not change behaviour relative to mobility via effort ( $p$-value $=0.00$ ).

${ }^{22}$ Here, we focus on the subgroup that believes immobility will lead to an increase in antisocial behaviour.

${ }^{23}$ We conduct a word frequency analysis using the responses to the open-ended questions. For each respondent we identify if they use a specified word. We then calculate the proportion of subjects that use at least one of the words in the specified word list.
} 
Suppose that there is low (high) mobility in this country. Is it appropriate for low-income groups to behave antisocially?

Potential responses range from very socially inappropriate to very socially appropriate on a four-point Likert scale. Approximately $40 \%$ of all respondents considered antisocial behaviour appropriate when income mobility is low (see Figure 1). In contrast, when income mobility is high, less than $20 \%$ report that antisocial behaviour is socially appropriate ( $p$-value $=0.00$ ). The social acceptability of antisocial behaviour may be lower when mobility is low relative to when mobility is high.

While this survey is useful to investigate public attitudes about immobility in different settings, it is not possible to make causal claims about the impact of POUM on antisocial behaviour, nor can we say much about the efficiency implications of immobility. In addition, survey respondents may suffer from socially desirable response bias. In contrast, laboratory experiments are better at overcoming these concerns. Importantly, laboratory experiments can measure causal impact and identify welfare effects by randomly assigning subjects to treatments where mobility is varied. The use of financial incentives may also reduce socially desirable response bias.

Our hypotheses from the intuitive framework, findings from the existing literature, and our evidence from the survey can be summarised as follows. We expect antisocial behaviour to be lower in treatments with mobility. We conjecture that this is because immobility is considered unfair and unjust, reducing the social acceptability of acting antisocially. We also conjecture that the initial income assignment influences antisocial behaviour, but it is not clear whether luck or effort will have the stronger effect. Finally, we hypothesize that the mobility mechanism influences the level of antisocial behaviour, with luck generating more antisocial behaviour.

\section{Results}

\subsection{Stage 1 Behaviour}


We begin by investigating behaviour in stage 1 . This stage is designed to create earnings differences between HI and LI types. As expected, HI types earn significantly more than LI types (721.46 and 355.01 experimental units, respectively, p-value $<0.001$, from a non-parametric Kruskal-Wallis test). We also investigate whether earnings differences exist across treatments. This may influence behaviour independent of any treatment effect, making treatment comparisons difficult. Results reported in Table 4 show no significant differences in the level of earnings across treatments (last column). ${ }^{24}$ This is reassuring as it suggests that upon commencing stage 2, subjects in each treatment are, on an average, similar in terms of earnings, excluding income differentials as a potential explanation of differences in antisocial behaviour across treatments.

\subsection{The impact of mobility}

In stage 2, subjects have an opportunity to attack others at a cost to themselves. To reveal the impact of POUM on antisocial behaviour, we compare attacking behaviour in treatments with mobility relative to the treatments without mobility. Since subjects have the opportunity to change income groups after the $10^{\text {th }}$ period of stage 2 , we separate behaviour into the first 10 periods (periods $1-10$ ) and the second 10 periods (periods $11-20$ ) of Stage 2. As we are primarily interested in how the prospect of mobility influences behaviour, we focus on decisions in the first 10 periods; however for completeness we discuss behaviour in the second 10 periods in Section 4.5.

Figure 2, panel A, illustrates antisocial behaviour in the mobility and immobility treatments in periods $1-10$. Overall, antisocial behaviour is always lower in the mobility treatments. Panel B, illustrates antisocial behaviour in the mobility and immobility treatments by income type and documents that this pattern is similar for both income groups.

\footnotetext{
${ }^{24} \mathrm{We}$ also compare the earnings in all the mobility treatments relative to the immobility treatments. We find that, on average, subjects in the mobility treatment earn 545.27 units relative to 529.01 in the immobility treatment $(\mathrm{p}$-value $=0.540)$.
} 
In Table 5A, columns 1 and 2, we report the mean rate of antisocial behaviour for mobility and immobility treatments. Column 3 shows the mean differences with p-values from Mann-Whitney rank sum tests shown in bold square brackets. We follow a conservative approach and treat each group of 10 as an individual observation. We find that antisocial behaviour in the immobility treatments is more than double that in the mobility treatments $(p$-value $=0.004)$. Both HI and LI types attack more frequently under immobility. HI types attack in $8.3 \%$ of cases in the mobility treatments relative to $17.2 \%$ in the immobility treatments $(p$-value $=0.025)$, similarly LI types in the mobility treatments attack in $10.6 \%$ of cases relative to $21.6 \%$ in the immobility treatments $(\mathrm{p}$-value $=$ 0.055). These results suggest that POUM leads to lower rates of antisocial behaviour. This is consistent with our prior expectations.

All subjects are informed of each group member's prior period earnings, cumulative earnings, and income type. As a result, a subject may direct attacks based on one's income group which may be affected by mobility. In Table 5A, rows $6-9$, we report attacking behaviour directed towards one's in-group and out-group. We find that HI types attack other HI types $6.8 \%$ of the time in the mobility treatment relative to $13.8 \%$ in the immobility treatment $(\mathrm{p}$-value $=$ 0.036). Income mobility also decreases antisocial behaviour directed by LI types towards HI types by $10 \%$. This finding is partially expected; if LI types believe they can move to the HI group, they may exhibit less animosity towards HI types, as they may one day join them. Also, LI types, knowing upward mobility is possible, but costly, may prefer to marshal (save or invest) their resource for an attempt at mobility as opposed to attacking HI types. HI types, being attacked less, are less inclined to (blindly) retaliate. This may lower the attacking behaviour directed towards the out-group. This is consistent with our expectations and with empirical evidence from the United States. Relative to 
other rich countries, low-income individuals in the United States are less likely to favor increasing taxes on the rich (Benabou and Ok 2001). ${ }^{25}$

To test the robustness of the non-parametric results, we estimate Equation 1 using a generalized least squares, random effects regression, with clustering at the group level.

$$
y_{i t}=\beta_{0}+\beta_{1} \text { Mobility }_{i t}+\partial_{1} X_{i t}+\varepsilon_{i t}
$$

The dependent variable $\left(y_{i t}\right)$ is a dummy variable which is equal to one when subject $i$ attacks another subject in period $t$ and zero otherwise. Our independent variable "Mobility ${ }_{i t}$ " is equal to 1 if subject ' $\mathrm{i}$ ' is allocated to a Mobility treatment and 0 otherwise. We also include " $X$ ", a vector of control variables including subject income type, period trend, whether a subject was the target of an attack in the last period, earnings in the previous period, relative income rank compared to other subjects, and gender. Results are presented in Table 6. In column 1, we report results as specified in equation 1. In column 2, the dependent variable restricts attacks targeting HI types only and column 3 characterises attacks targeting LI types.

Consistent with the non-parametric outcomes, POUM appears to reduce antisocial behaviour (Table 6 , column 1). The reduction in antisocial behaviour under mobility appears to benefit HI types. POUM reduces antisocial behaviour directed towards HI types by 8.2 percentage points; on the other hand, mobility has little impact on antisocial behaviour targeting LI types. This is likely because antisocial behaviour targeting this group is uncommon.

To understand whether mobility favours the in-group or out-group, we estimate equation 1 separately for HI and LI types (see Table 7). There are two key points that emerge from this table: 1) mobility reduces the frequency of HI types targeting HI types, but it does not change their antisocial behaviour towards LI types. Again, this is likely because HI types almost never attack LI

\footnotetext{
${ }^{25}$ In the third stage VCM game, we find that contributions to the public good are not significantly different across the mobility and immobility treatments.
} 
types; and 2) POUM reduces LI types' antisocial behaviour towards HI types, but it increases attacks targeting fellow LI types. These results are consistent with the non-parametric results. We speculate that the behaviour of LI types may be the result of a weaker group identity. The potential of LI types to change their income group may reduce their in-group bond relative to immobility where changing in-group is not possible. LI types may also regard other LI types as their rivals, thus increasing antisocial behaviour.

To assess the impact of POUM on earnings, a proxy for welfare, we make a back-of-the-envelope assessment of the lower bound for the cost of antisocial behaviour in the mobility and immobility treatments. ${ }^{26}$ Each attack costs society 25 cents ( 5 cents for the perpetrator and 20 cents for the target). On average, subjects attack $19.7 \%$ of the time in the immobility treatment, reducing societal earnings by 492.5 cents $(19.7 * 25)$, and individual earnings by 49.25 cents. In contrast, in the mobility treatment subjects attack in $9.48 \%$ of cases reducing average societal earnings by 237 cents and individual earnings by 23.7 cents. $^{27}$

Using average total individual earnings at the end of the $10^{\text {th }}$ period, antisocial behaviour in the immobility treatment reduces earnings by $5.05 \%$ while antisocial behaviour in the mobility treatment reduces earnings by $2.38 \%$, close to half the reduction in earnings. This suggests that in this context, immobility has significant welfare consequences.

\subsection{The heterogeneity of mobility}

There are at least two components of mobility that may influence behaviour. The first is the initial income endowment (i.e., the mechanism assigning subjects to their initial income group). We test behaviour when a subject's initial income is assigned through luck or through effort. The second is the mechanism by which mobility can occur, either through luck or effort. In this subsection,

\footnotetext{
${ }^{26} \mathrm{We}$ assume (conservatively) that money spent attacking or lost from an attack would have been saved. Instead, subjects could have invested this money with a positive expected rate of return. In our data, we find that most subjects did in fact invest, hence this is a conservative assumption.

${ }^{27} \mathrm{We}$ calculate this under the assumption that all else would have been equal without the attacks.
} 
we investigate how the initial assignment, the mobility mechanism, and the interaction between these two factors affect behaviour.

\subsubsection{Initial Income Group Assignment}

We are interested in two comparisons: first, the impact of POUM when initial income is assigned by luck and when it is assigned by effort, and second, the impact of initial income assigned by effort relative to luck. To understand the impact of mobility under the different assignment mechanisms, we compare antisocial behaviour in our immobility treatments to our mobility treatments. We combine the Luck/Luck and the Luck/Effort treatments (i.e., Luck/Mobility) and compare this merged treatment with the Luck/Immobility treatment. Similarly, we combine the Effort/Luck and Effort/Effort treatments to create an Effort/Mobility treatment and compare this with the Effort/Immobility treatment. These comparisons highlight the impact of mobility when initial income is assigned by luck (effort). We report means and results from non-parametric tests in Table 5B, columns $1-8$. When subjects' income groups are mobile and initial income is assigned by luck, attacks occur in $6 \%$ of cases relative to $17 \%$ when subjects are immobile ( $p$-value $=0.001$ ). Similarly, when subjects' income groups are mobile and initial income is assigned by effort, attacks occur in $13 \%$ of cases relative to $21 \%$ when subjects are immobile, but the difference is statistically insignificant ( $p$-value $=0.13$ ).

Turning to the effect of luck relative to effort, we compare Luck/Mobility to Effort/Mobility in column 7 and observe almost double the rate of antisocial behaviour in Effort/Mobility relative to Luck/Mobility (13\% vs. 6\%, p-value = 0.012). However, if we directly compare Luck/Immobility to Effort/Immobility in column 8 , we find little difference in antisocial behaviour (17\% vs. $21 \%$, pvalue $=0.54)$.

We observe a similar pattern when investigating behaviour by income type. When the initial income is assigned by luck, mobility leads to fewer attacks by both HI and LI types targeting HI types ( $\mathrm{p}$-value $=0.07$ and 0.05 , respectively). This pattern is not observed when the initial income is assigned by effort ( $p$ - 
value $>0.25$ in both cases). When we again empirically test for differences between Luck/Mobility relative to Effort/Mobility (column 10) by income assignment, we find that LI types in Effort/Mobile attack at close to three times the rate of LI types in Luck/Mobility ( $p$-value $=0.021$ ), and they predominately attack HI types ( $p$-value $=0.070)$. On the other hand, without mobility (Effort/Immobility and Luck/Immobility) there do not appear to be differences in rates of attacks between assignment mechanisms (column 8). The key exception is attacks towards LI types. When initial income is assigned by effort, attacks towards LI types occur around $5.5 \%$ of the time relative to $1.4 \%$ when initial income is assigned by luck ( $\mathrm{p}$-value $=0.030$ ). These attacks appear to be predominately driven by other LI types.

We examine the robustness of this result by estimating the following model:

$$
y_{i t}=\beta_{0}+\beta_{1} L M_{i t}+\beta_{2} E M_{i t}+\beta_{3} E I_{i t}+\partial_{1} X_{i t}+\varepsilon_{i t}
$$

Here the first letter refers to the mechanism assigning initial endowments (E for effort and L for luck) while the second letter represents the prospect of mobility ( $\mathrm{M}$ for mobile and I for immobile). Other than these differences, the estimation is identical to equation 1 . The excluded category is luck/immobility. Results reported in Table 8, column 1, show antisocial behaviour in general; columns 2 and 3 report antisocial behaviour targeting HI and LI types, respectively. Panel B reports the comparison between luck with and without mobility.

Similar to the non-parametric results, we find that when the initial income is assigned by luck, mobility reduces antisocial behaviour relative to luck without mobility. Subjects initially assigned their income groups through luck (Luck/Mobility) attack 11 percentage points less often relative to Luck/Immobility. The reduction in antisocial behaviour benefits HI types, who are attacked 11 percentage points less often. Unlike the non-parametric results, we also find that when initial income is based on effort, mobility reduces antisocial behaviour by 8 percentage points relative to a setting where income 
mobility is not possible. This difference is statistically significant at the margin $(\mathrm{p}$-value $=0.096)$.

Finally, as before, we directly compare how the mechanism for assigning initial income influences behaviour. We find identical results to the nonparametric findings (see Table 8). These results suggest that antisocial behaviour in general, and antisocial behaviour directed towards HI types in particular, are not influenced by the initial income assignment in and of itself, but rather by the combination of initial allocation and mobility.

\subsubsection{Mobility Mechanisms}

To investigate whether the mobility mechanisms affect antisocial behaviour, we hold the initial income assignment constant and compare Luck/Luck with Luck/Immobility and Effort/Effort with Effort/Immobility. These comparisons are illustrated in Figure 3, Panels A and B. Panel A shows antisocial behaviour in treatments where initial income is assigned by luck; Panel B shows antisocial behaviour in treatments where initial income is assigned by effort. In both panels, we observe higher rates of antisocial behaviour in the immobility treatments across all periods.

Mean antisocial behaviour is reported in Tables 9A and 9B. Table 9A, column 4, reports the difference between Luck/Luck and Luck/Immobility while Table 9B, column 4, shows the difference between Effort/Luck and Effort/Immobility. We find that relative to Luck/Immobility, the prospect of mobility based on luck reduces antisocial behaviour by more than $50 \%$ (p-value $=0.055)$. It is HI types who benefit most from LI types' prospect of mobility; antisocial behaviour targeting $\mathrm{HI}$ types declines from $15.7 \%$ to $5.6 \%$ under Luck/Luck. Similarly, when initial income occurs through effort, attacks occur less often in Effort/Luck relative to Effort/Immobile (20.0\% vs. 12.9\%) but this difference is insignificant ( $p$-value $=0.25$ ). When we examine mobility based on Effort, we find similar results; when initial income occurs through luck, antisocial behaviour is reduced to $4 \%$ relative to $17 \%$ in Luck/Immobility (pvalue $=0.007)$. However, when we examine the case where initial income 
occurs through effort we cannot conclusively identify differences between Effort/Immobility and Effort/Effort.

Next, we directly compare the two mobility mechanisms. Comparing Luck/Luck (Effort/Luck) and Luck/Effort (Effort/Effort) allows us to examine the impact of mobility via luck relative to effort, holding the mechanism for allocating original income constant. Table 9A, column 6, reports the difference between Luck/Luck and Luck/Effort while Table 9B, column 12, shows the difference between Effort/Luck and Effort/Effort. We find that in both comparisons, mean attacking behaviour is lower when mobility occurs via effort relative to luck; however, differences are not statistically significant ( $\mathrm{p}$-value = 0.137 and 0.896 , respectively).

We examine the robustness of this result by estimating the following model:

$$
y_{i t}=\beta_{0}+\beta_{1} E \mathrm{I}_{i t}+\beta_{2} L L_{i t}+\beta_{3} E L_{i t}+\beta_{4} L E_{i t}+\beta_{5} E E_{i t}+\partial_{1} X_{i t}+\varepsilon_{i t}
$$

The first letter refers to the initial income assignment mechanism (E for effort, L for luck), while the second represents the mobility mechanism. Other than these differences, the estimation is identical to equation 1. The excluded treatment is Luck/Immobility. Results are reported in Table 10, column 1. In Panel B, we identify the effect of the mobility mechanism relative to immobility with (Effort/Immobility - Effort/Effort) and (Luck/Immobility - Luck/Luck). We also identify the relative impact of the mobility mechanisms with (Luck/Luck - Luck/Effort) and (Effort/Luck - Effort/Effort). The regression results corroborate the results found using non-parametric methods.

We examine the heterogeneity further in Table 10 by estimating equation 3 for HI and LI types separately. Columns 2 and 3 report antisocial behaviour targeting HI and LI types, respectively. The key comparisons (Luck/Luck Luck/Effort) and (Effort/Luck - Effort/Effort) are reported in Panel B. Like the non-parametric results, we find that antisocial behaviour appears to be less in the case of effort but differences are not statistically significant. While the 
direction of the difference is consistent with our expectation these results show that POUM, whether through luck or effort, reduces antisocial behaviour and at similar rates.

\subsection{Intentions of Mobility}

Although POUM appears to be important for antisocial behaviour, another important factor is whether one attempts to move up the income distribution. Across all mobility treatments, $67 \%$ of LI types attempt to change income class. In this section, we consider if those who attempt mobility behave differently from those who did not try.

In Table A1, panel A, we report the antisocial behaviour of LI types in periods $11-20$ in the mobility treatments. This subgroup can move up the income distribution. In column 1 (column 2), we show behaviour of those LI types who attempted (did not attempt) to change income type. We find little difference in rates of antisocial behaviour between the two groups. Those who attempted to change their income group and those who did not both attack at a rate of $8 \%(p$-value $=0.612)$. Similarly, we find no evidence that these groups attack HI or LI types at a different rate. Results from a random effects model confirm these results. ${ }^{28}$ This suggests that whether someone attempts income change is not the main factor in the reduction in antisocial behavior; the prospect, in and of itself, appears to be sufficient.

\subsection{The Implications of Mobility}

Although our main interest is in POUM rather than actual income mobility, how do subjects behave after the mobility mechanism is implemented is an important question. In Table A1, panel B, we compare antisocial behaviour in the periods $11-20$ of those who attempted to change $(67 \%, 71 / 105$ of LI) relative to those who did not. We find little difference in rates of antisocial behaviour; LI types who attempted to change do not attack at a different rate.

Subjects who attempted to change can be further broken into two categories, those who were successful $(23 \%, 16 / 71$ of attempting LI's) and those who were

\footnotetext{
${ }^{28}$ Regression results available on request.
} 
unsuccessful. We compare these two groups in panel C. We find some evidence that those who unsuccessfully attempted to change attack at a higher rate relative to the new HI types. However, these differences are not statistically significant $(p$-value $=0.645)$. These results should be interpreted with caution, due to the low number of observations at this finer grained level of analysis.

For completeness, we re-estimate and report all empirical estimations for Stage 2, periods $11-20$. By this stage, subjects have either successfully or unsuccessfully moved up the income distribution. Results are reported in Table A2 to Table A7. Results are very similar to those found in periods $1-10$. More specifically, in periods $11-20$, the mobility treatments have lower rates of attacking behaviour than the immobility treatments $(5.1 \%$ versus $13.8 \%$, pvalue $=0.004) .{ }^{29}$ We also observe both fewer attacks by HI $(4.9 \%$ versus $11.8 \%$, p-value $=0.090$ ), even though there is now more of them, and fewer attacks by LI types $(5.4 \%$ versus $15.8 \%$, p-value $=0.015)$. Hence, the prospect of mobility not only reduces antisocial behaviour while the possibility exists, but this reduction persists even after the possibility has passed.

\section{Conclusion}

The prospect of upward income mobility (POUM) has long interested economists and social scientists. With growing evidence of a decline in realized upward income mobility, the topic has recently attracted the attention of policy makers. President Obama passionately denounced the narrow opportunities for upward mobility from the bottom of the income scale as a "betrayal of the American ideal." Despite this interest and a growing pool of research on the topic, there is still little research on the impact of the prospect of mobility on antisocial behaviour, a plausible yet unexplored cost of immobility.

Using a survey and an innovative experimental design, this paper examines the impact of POUM on antisocial behaviour. Survey evidence suggests that a

\footnotetext{
${ }^{29}$ These results should be interpreted with caution. In the second 10 periods, selection bias is likely an issue. In the mobility treatments, there are less LI subjects and those that remain are likely to be different from those that were LI and became HI. This makes the comparison of mobility to immobility difficult.
} 
lack of income mobility will increase antisocial behaviour. This result is corroborated in the experiment where we find that the prospect of mobility reduces antisocial behaviour and, in particular, potential beneficiaries of mobility (i.e., those of low income) are less likely to direct antisocial behaviour towards high-income group members.

A natural question is whether antisocial behaviour depends on the process of income generation or how a person moves up the income distribution. To answer this question, our experimental design consists of treatments that vary subjects' initial income assignments and their methods of mobility. We find that the income assignment mechanism has an impact on antisocial behaviour, but only in treatments where mobility is possible. Furthermore, there does not appear to be any statistically meaningful difference in antisocial behaviour between the different mobility mechanisms. This indicates that POUM itself, rather than how one moves, is an important factor explaining antisocial behaviour. These results suggest that the prospect of upward mobility, or more specifically immobility, may have important implications for societal welfare. As mobility continues to decline, there is potential for backlash, particularly from those at the lower rungs of society. Policymakers cannot ignore this potentially costly consequence of immobility.

\section{References}

Alesina, A., Glaeser, E. and Sacerdote, B., 2001. Why doesn't the US have a European-style Welfare System? National bureau of economic research. Working Paper 8524.

Alesina, A., Stantcheva, S., and Teso, E. 2017. Intergenerational Mobility and Support for Redistribution. Technical report, National Bureau of Economic Research. Working Paper 23027.

Almås, I., Cappelen, A.W., Sørensen, E.O., and Tungodden, B. 2010. Fairness and the development of inequality acceptance. Science 328(5982), 11761178 . 
Benabou, R., and Ok, E. 2001. Social Mobility and the Demand for Redistribution: The POUM Hypothesis. Quarterly Journal of Economics, $447-487$

Brunori, P., Ferreira, G., and Peragine, V. 2013. Inequality of Opportunity, Income Inequality and Economic Mobility: Some International Comparisons. Policy Research Working Paper 6304, World Bank, Washington, DC.

Cappelen, A.W., Konow J., Sørensen E.Ø., Tungodden, B. 2013. Just Luck: An Experimental Study of Risk Taking and Fairness. American Economic Review, 103: 1398-1413

Chadwick L., and Solon, G. 2002. Intergenerational Income Mobility among Daughters. American Economic Review, 92: 335-44.

Chetty, R, Grusky, D., Hell, M., Hendren, N., Manduca, R., and Narang, J. 2017. The Fading American Dream: Trends in Absolute Income Mobility since 1940. Science, 356: 398-406

Chetty, R., Hendren, N. Kline, P., and Saez, E. 2014a. Where is the Land of Opportunity? The Geography of Intergenerational Mobility in the United States. Quarterly Journal of Economics, 129:1553-1623.

Chetty, R., Hendren, N., Kline, P., Saez, E., and Turner, N. 2014b. Is the United States Still a Land of Opportunity? Recent Trends in Intergenerational Mobility. American Economic Review, 104: 141-147

Cojocaru, A., 2014. Prospects of Upward Mobility and Preferences for Redistribution: Evidence from the Life in Transition Survey. European Journal of Political Economy, 34: 300-314.

Congressional Budget Office. 2016. Trends in Family Wealth, 1989 to 2013. Congress of the United States, Congressional Budget Office.

Dawes, C.T., Fowler, J.H., Johnson, T., McElreath, R. and Smirnov, O., 2007. Egalitarian motives in humans. Nature, 446: 794.

Fehr, E., and Schmidt, K. 1999. A Theory of Fairness, Competition, and Cooperation. Quarterly Journal of Economics, 114: 817-868. 
Fischbacher, U. 2007. z-Tree: Zurich Toolbox for Ready-Made Economic Experiments. Experimental Economics, 10: 171-178.

Fox, S. and Spector, P. E. 1999. A model of work frustration-aggression. Journal of Organizational Behavior, 20: 915-931.

Gino, F. and Pierce, L. 2009a. Dishonesty in the name of equity. Psychological Science 20: 1153-1160.

Gino F. and Pierce L. 2009b. The abundance effect: Unethical behavior in the presence of wealth. Organizational Behavior and Human Decision Processes 109: 142-155.

Greiner, B. 2015. Subject Pool Recruitment Procedures: Organizing Experiments with ORSEE. Journal of the Economic Science Association, 1: $114-125$.

Lee, C.I. and Solon, G. 2009. Trends in Intergenerational Income Mobility. Review of Economics and Statistics, 91: 766-772.

Putterman, L. 1997. Why have the Rabble not Redistributed the Wealth? On the Stability of Democracy and Unequal Property. In Property Relations, Incentives and Welfare. Palgrave Macmillan UK, 359-393.

OECD. 2011. An Overview of Growing Income Inequalities in OECD Countries: Main Findings. http://search.oecd.org/els/soc/49499779.pdf

OECD. 20I6. Income and Wealth Inequality in OECD Countries. https://archiv.wirtschaftsdienst.eu/jahr/2016/13/income-and-wealthinequality-in-OECD-countries/

Rabin, M. 1993. Incorporating Fairness into Game Theory and Economics. American Economic Review, 1281-1302.

Roemer, J.E. 1998. Why the Poor Do Not Expropriate the Rich: An Old Argument in New Garb. Journal of Public Economics, 70: 399-424.

Samuel, L. 2012. The American Dream: A Cultural History. Syracuse, NY: Syracuse University Press.

Solon, G. 2002. Cross-Country Differences in Intergenerational Earnings Mobility. Journal of Economic Perspectives, 16: 59-66. 
van de Ven, N., Zeelenberg, M., and Pieters, R. 2009. Leveling Up and Down:

The Experiences of Benign and Malicious Envy. Emotion, 9: 419-429.

Table 1: Treatment details

\begin{tabular}{ccccc}
\hline Treatment & $\begin{array}{c}\text { Stage 1: } \\
\text { Income class } \\
\text { assignment }^{\mathrm{a}}\end{array}$ & $\begin{array}{c}\text { Stage 2: } \\
\text { Income class } \\
\text { mobility }^{\mathrm{b}}\end{array}$ & Sessions & N \\
\hline Luck/Immobility & Random & No Change & 7 & 70 \\
Effort/Immobility & Counting Zeros & No Change & 9 & 90 \\
Luck/Luck & Random & Random & 3 & 50 \\
Luck/Effort & Random & Counting Zeros & 6 & 60 \\
Effort/Effort & Counting Zeros & Counting Zeros & 5 & 50 \\
Effort/Luck & Counting Zeros & Random & 5 & 50 \\
\hline
\end{tabular}

a - Income class for Stage 1 and Stage 2, periods $1-10$.

$\mathrm{b}$ - Income class for Stage 2, periods $11-20$

Table 2: Summary of predictions

\begin{tabular}{lccc}
\hline & $\begin{array}{c}\text { Mobility } \\
\text { vs } \\
\text { Immobility }\end{array}$ & $\begin{array}{c}\text { Initial Income } \\
\text { Luck vs Effort }\end{array}$ & $\begin{array}{c}\text { Mobility } \\
\text { Luck vs Effort }\end{array}$ \\
\hline $\begin{array}{l}\text { Impact on Antisocial } \\
\text { Behaviour }\end{array}$ & Decrease $(\downarrow)$ & $\begin{array}{c}\text { Ambigious } \\
(\rightarrow)\end{array}$ & Increase $(\uparrow)$ \\
\hline
\end{tabular}

Notes: The arrows indicate the change in antisocial behaviour for treatment comparisons. When we consider the predictions of mobility via luck or effort, we hold initial income assignment constant. 
Table 3: Initial Income Allocation, Mobility and Pro and Antisocial Behaviour

\begin{tabular}{|c|c|c|c|c|c|c|c|}
\hline \multirow[b]{2}{*}{ Row } & \multirow[b]{2}{*}{ Response } & \multicolumn{3}{|c|}{ Panel A: Initial Income Allocation } & \multicolumn{3}{|c|}{ t-test p-value } \\
\hline & & $\begin{array}{c}\text { General } \\
\text { (1) }\end{array}$ & $\begin{array}{l}\text { Luck } \\
\text { (2) }\end{array}$ & $\begin{array}{c}\text { Effort } \\
(3)\end{array}$ & $(1-2)$ & $(1-3)$ & $(2-3)$ \\
\hline 1 & $\begin{array}{l}\text { Antisocial } \\
\text { behaviour }\end{array}$ & $77.6 \%$ & $64.5 \%$ & $58.2 \%$ & 0.00 & 0.00 & 0.13 \\
\hline 2 & $\begin{array}{l}\text { No change } \\
\text { in } \\
\text { behaviour }\end{array}$ & $12.2 \%$ & $23.2 \%$ & $27.8 \%$ & 0.00 & 0.00 & 0.22 \\
\hline 3 & $\begin{array}{l}\text { Prosocial } \\
\text { behaviour }\end{array}$ & $10.1 \%$ & $12.2 \%$ & $13.9 \%$ & 0.425 & 0.180 & 0.538 \\
\hline Row & & $\begin{array}{c}\text { General } \\
(1)\end{array}$ & $\begin{array}{c}\text { Pane } \\
\text { Effort } \\
(2) \\
\end{array}$ & $\begin{array}{l}\text { Mobility } \\
\text { Luck } \\
(3)\end{array}$ & $1-2$ & $1-3$ & $2-3$ \\
\hline 4 & $\begin{array}{l}\text { Antisocial } \\
\text { behaviour }\end{array}$ & $77.6 \%$ & $7.6 \%$ & $26.2 \%$ & 0.00 & 0.00 & 0.00 \\
\hline 5 & $\begin{array}{l}\text { No change } \\
\text { in } \\
\text { behaviour }\end{array}$ & $12.2 \%$ & $20.3 \%$ & $40.0 \%$ & 0.01 & 0.00 & 0.00 \\
\hline 6 & $\begin{array}{l}\text { Prosocial } \\
\text { behaviour }\end{array}$ & $10.1 \%$ & $72.2 \%$ & $33.8 \%$ & 0.00 & 0.00 & 0.00 \\
\hline
\end{tabular}

Note: The last three columns show the significance of difference in mean responses using a t-test. For instance, the fourth column reports the significance of differences between column 1 and 2

Table 4: Average earnings at the end of the Stage 1, treatment comparison

\begin{tabular}{|c|c|c|c|c|c|c|}
\hline \multicolumn{2}{|c|}{$\begin{array}{l}\text { Immobility } \\
\text { Treatments }\end{array}$} & & \multicolumn{2}{|c|}{ Mobility Treatments } & & \\
\hline Luck & Effort & Luck/Luck & $\begin{array}{l}\text { Effort/ } \\
\text { Luck }\end{array}$ & $\begin{array}{l}\text { Luck/ } \\
\text { Effort }\end{array}$ & $\begin{array}{l}\text { Effort/ } \\
\text { Effort }\end{array}$ & $\mathrm{K}-$ Wallis \\
\hline 524.14 & 532.78 & 547.84 & 551.27 & 543.96 & 536.80 & $\chi^{2}=4.78$ \\
\hline$(8.79)$ & (34.34) & $(9.55)$ & (15.40) & (14.50) & (10.50) & $\mathrm{p}=0.44$ \\
\hline
\end{tabular}

Note: Standard errors are reported in parentheses and results from a Kruskal-Wallis test are reported in the last column. 
Table 5A: Attacking behaviour, mobility versus immobility, Stage 2, periods 1-10.

\begin{tabular}{llll}
\hline Variable & Mobility & Immobility & $\begin{array}{l}\text { Diff } \\
(1-2)\end{array}$ \\
& $(1)$ & $(2)$ & $(3)$ \\
\hline 1. Attacks & 0.095 & 0.194 & 0.099 \\
& $(0.014)$ & $(0.026)$ & {$[\mathbf{0 . 0 0 4}]$} \\
2.Attacks by HI & 0.083 & 0.171 & 0.088 \\
& $(0.018)$ & $(0.0334)$ & {$[\mathbf{0 . 0 2 5}]$} \\
3. Attacks by LI & 0.106 & 0.216 & 0.110 \\
& $(0.022)$ & $(0.216)$ & {$[\mathbf{0 . 0 5 5}]$} \\
4. Attacks & 0.073 & 0.157 & 0.084 \\
towards HI & $(0.012)$ & $(0.024)$ & {$[\mathbf{0 . 0 0 5}]$} \\
5. Attacks & 0.022 & 0.037 & 0.015 \\
towards LI & $(0.007)$ & $(0.020)$ & {$[0.208]$} \\
6. Attacks by HI & 0.068 & 0.139 & 0.070 \\
towards HI & $(0.017)$ & $(0.031)$ & {$[\mathbf{0 . 0 3 6}]$} \\
7. Attacks by LI & 0.077 & 0.175 & 0.098 \\
towards HI & $(0.017)$ & $(0.036)$ & {$[\mathbf{0 . 0 7 7}]$} \\
8. Attacks by HI & 0.015 & 0.033 & 0.017 \\
towards LI & $(0.004)$ & $(0.011)$ & {$[0.433]$} \\
9. Attacks by LI & 0.029 & 0.041 & 0.012 \\
towards LI & {$[0.013]$} & {$[0.016]$} & {$[0.340]$} \\
\hline
\end{tabular}


Table 5B: Attacking behaviour, mobility versus immobility, Stage 2, periods 1-10.

\begin{tabular}{|c|c|c|c|c|c|c|c|c|}
\hline Variable & $\begin{array}{l}\text { Luck/ } \\
\text { Mobility } \\
\text { (1) }\end{array}$ & $\begin{array}{l}\text { Luck/ } \\
\text { Immobility } \\
\text { (2) }\end{array}$ & $\begin{array}{l}\text { Diff } \\
(4-5) \\
(3)\end{array}$ & $\begin{array}{l}\text { Effort/ } \\
\text { Mobility } \\
\text { (4) }\end{array}$ & $\begin{array}{l}\text { Effort/ } \\
\text { Immobility } \\
(5)\end{array}$ & $\begin{array}{l}\text { Diff } \\
(7-8) \\
(6)\end{array}$ & $\begin{array}{l}\text { Diff } \\
(4-7) \\
(7)\end{array}$ & $\begin{array}{l}\text { Diff } \\
(5-8) \\
(8)\end{array}$ \\
\hline 1. Attacks & $\begin{array}{l}0.057 \\
(0.014)\end{array}$ & $\begin{array}{l}0.172 \\
(0.035)\end{array}$ & $\begin{array}{l}-0.114 \\
{[0.006]}\end{array}$ & $\begin{array}{l}0.129 \\
(0.021)\end{array}$ & $\begin{array}{l}0.211 \\
(0.038)\end{array}$ & $\begin{array}{l}-0.082 \\
{[0.134]}\end{array}$ & $\begin{array}{l}0.072 \\
{[\mathbf{0 . 0 1 2}]}\end{array}$ & $\begin{array}{l}-0.040 \\
{[0.542]}\end{array}$ \\
\hline 2.Attacks by HI & $\begin{array}{l}0.060 \\
(0.023)\end{array}$ & $\begin{array}{l}0.134 \\
(0.034)\end{array}$ & $\begin{array}{l}-0.074 \\
{[\mathbf{0 . 0 4 4}]}\end{array}$ & $\begin{array}{l}0.105 \\
(0.027)\end{array}$ & $\begin{array}{l}0.200 \\
(0.054)\end{array}$ & $\begin{array}{l}-0.095 \\
{[0.159]}\end{array}$ & $\begin{array}{l}0.0449 \\
{[0.227]}\end{array}$ & $\begin{array}{l}-0.077 \\
{[0.317]}\end{array}$ \\
\hline 3. Attacks by LI & $\begin{array}{l}0.054 \\
(0.017)\end{array}$ & $\begin{array}{l}0.209 \\
(0.062)\end{array}$ & $\begin{array}{l}-0.154 \\
{[\mathbf{0 . 0 6 9}]}\end{array}$ & $\begin{array}{l}0.154 \\
(0.033)\end{array}$ & $\begin{array}{l}0.222 \\
(0.058)\end{array}$ & $\begin{array}{l}-0.069 \\
{[0.403]}\end{array}$ & $\begin{array}{l}0.099 \\
{[\mathbf{0 . 0 2 1}]}\end{array}$ & $\begin{array}{l}-0.003 \\
{[0.975]}\end{array}$ \\
\hline $\begin{array}{l}\text { 4. Attacks } \\
\text { towards HI }\end{array}$ & $\begin{array}{l}0.044 \\
(0.013)\end{array}$ & $\begin{array}{l}0.157 \\
(0.035)\end{array}$ & $\begin{array}{l}-0.113 \\
{[\mathbf{0 . 0 0 4}]}\end{array}$ & $\begin{array}{l}0.099 \\
(0.018)\end{array}$ & $\begin{array}{l}0.157 \\
(0.033)\end{array}$ & $\begin{array}{l}-0.058 \\
{[0.236]}\end{array}$ & $\begin{array}{l}0.055 \\
{[\mathbf{0 . 0 1 4}]}\end{array}$ & $\begin{array}{l}0.000 \\
{[0.894]}\end{array}$ \\
\hline $\begin{array}{l}\text { 5. Attacks } \\
\text { towards LI }\end{array}$ & $\begin{array}{l}0.013 \\
(0.004)\end{array}$ & $\begin{array}{l}0.014 \\
(0.009)\end{array}$ & $\begin{array}{l}-0.001 \\
{[0.748]}\end{array}$ & $\begin{array}{l}0.030 \\
(0.013)\end{array}$ & $\begin{array}{l}0.054 \\
(0.015)\end{array}$ & $\begin{array}{l}-0.024 \\
{[\mathbf{0 . 0 7 9}]}\end{array}$ & $\begin{array}{l}0.017 \\
{[0.516]}\end{array}$ & $\begin{array}{l}-0.040 \\
{[\mathbf{0 . 0 3 0}}\end{array}$ \\
\hline $\begin{array}{l}\text { 6. Attacks by HI } \\
\text { towards HI }\end{array}$ & $\begin{array}{l}0.042 \\
(0.021)\end{array}$ & $\begin{array}{l}0.111 \\
(0.029)\end{array}$ & $\begin{array}{l}-0.069 \\
{[\mathbf{0 . 0 6 8}]}\end{array}$ & $\begin{array}{l}0.092 \\
(0.026)\end{array}$ & $\begin{array}{l}0.160 \\
(0.052)\end{array}$ & $\begin{array}{l}-0.068 \\
{[0.252]}\end{array}$ & $\begin{array}{l}0.0503 \\
{[\mathbf{0 . 0 7 5}]}\end{array}$ & $\begin{array}{l}-0.045 \\
{[0.584]}\end{array}$ \\
\hline $\begin{array}{l}\text { 7. Attacks by LI } \\
\text { towards HI }\end{array}$ & $\begin{array}{l}0.046 \\
(0.017)\end{array}$ & $\begin{array}{r}0.203 \\
(0.060)\end{array}$ & $\begin{array}{l}-0.157 \\
{[\mathbf{0 . 0 4 8}]}\end{array}$ & $\begin{array}{l}0.105 \\
(0.026)\end{array}$ & $\begin{array}{l}0.153 \\
(0.045)\end{array}$ & $\begin{array}{l}-0.048 \\
{[0.703]}\end{array}$ & $\begin{array}{l}0.059 \\
{[\mathbf{0 . 0 7 0}]}\end{array}$ & $\begin{array}{l}0.046 \\
{[0.447]}\end{array}$ \\
\hline $\begin{array}{l}\text { 8. Attacks by HI } \\
\text { towards LI }\end{array}$ & $\begin{array}{l}0.018 \\
(0.007)\end{array}$ & $\begin{array}{l}0.023 \\
(0.017)\end{array}$ & $\begin{array}{l}-0.005 \\
{[0.916]}\end{array}$ & $\begin{array}{l}0.012 \\
(0.004)\end{array}$ & $\begin{array}{l}0.040 \\
(0.016)\end{array}$ & $\begin{array}{l}-0.027 \\
{[0.281]}\end{array}$ & $\begin{array}{l}-0.005 \\
{[0.822]}\end{array}$ & $\begin{array}{l}-0.031 \\
{[0.196]}\end{array}$ \\
\hline $\begin{array}{l}\text { 9. Attacks by LI } \\
\text { towards LI }\end{array}$ & $\begin{array}{l}0.008 \\
(0.004)\end{array}$ & $\begin{array}{l}0.006 \\
(0.004)\end{array}$ & $\begin{array}{l}0.002 \\
{[0.761]}\end{array}$ & $\begin{array}{l}0.048 \\
(0.024)\end{array}$ & $\begin{array}{l}0.069 \\
(0.025)\end{array}$ & $\begin{array}{l}-0.021 \\
(0.035)\end{array}$ & $\begin{array}{l}0.040 \\
{[0.240]}\end{array}$ & $\begin{array}{l}-0.049 \\
{[\mathbf{0 . 0 3 5}]}\end{array}$ \\
\hline
\end{tabular}

Note: Standard errors reported in brackets. P-values from Wilcoxon Rank Sum reported in square brackets. 
Table 6: Random effects regression estimation of antisocial behaviour in Stage 2, periods $1-10$.

\begin{tabular}{cccc}
\hline & $(1)$ & $(2)$ & $(3)$ \\
& Attack & Attack HI & Attack LI \\
\hline Mobility & $-0.095^{* * *}$ & $-0.082^{* * *}$ & -0.013 \\
LI Subject & $(0.033)$ & $(0.028)$ & $(0.010)$ \\
& -0.046 & -0.051 & 0.002 \\
Period & $(0.032)$ & $(0.032)$ & $(0.020)$ \\
& $-0.010^{* * *}$ & $-0.008^{* * *}$ & $-0.003 * * *$ \\
Male subject & $(0.002)$ & $(0.002)$ & $(0.001)$ \\
& 0.022 & 0.018 & 0.005 \\
Rank & $(0.025)$ & $(0.022)$ & $(0.010)$ \\
& $-0.014 * * *$ & $-0.014 * * *$ & -0.002 \\
Earnings in last round & $(0.005)$ & $(0.005)$ & $(0.003)$ \\
& $-0.000^{*}$ & $-0.000^{* *}$ & -0.000 \\
Attacked in last round & $(0.000)$ & $(0.000)$ & $(0.000)$ \\
& $0.036^{* *}$ & 0.017 & 0.019 \\
Constant & $(0.018)$ & $(0.016)$ & $(0.019)$ \\
& $0.350^{* * *}$ & $0.302 * * *$ & $0.057 *$ \\
Number of subjects & $(0.051)$ & $(0.055)$ & $(0.030)$ \\
& 37,700 & 3,700 & 3,700 \\
& 370 & 370 & 370 \\
\hline
\end{tabular}

Note: Estimates from Random effects regressions with standard errors, clustered at the group level, in parentheses. Column 1 reports attacks directed towards j; Column 2 (3) reports antisocial behaviour directed towards $\mathrm{HI}(\mathrm{LI}) .{ }^{* * *} \mathrm{p}<0.01,{ }^{*} \mathrm{p}<0.05,{ }^{*} \mathrm{p}<0.1$

Table 7: Random effects regression, antisocial behaviour, Stage 2, periods 110 , by subject type.

\begin{tabular}{lcccccc}
\hline \multicolumn{3}{c}{ HI's Only } & \multicolumn{5}{c}{ LI's Only } \\
\hline & $(1)$ & $(2)$ & $(3)$ & $(4)$ & $(5)$ & $(6)$ \\
& Attack & Attack HI Attack LI & Attack & Attack HI & Attack LI \\
\hline \multirow{3}{*}{ Mobility } & & & & & & \\
& $-0.085^{* *}$ & $-0.069^{* *}$ & -0.017 & $-0.112 * *$ & $-0.100^{* *}$ & -0.011 \\
Period Trend & $(0.037)$ & $(0.035)$ & $(0.012)$ & $(0.045)$ & $(0.040)$ & $(0.020)$ \\
& $-0.005^{* * *}$ & -0.002 & $-0.003 * *$ & $-0.015^{* * *}$ & $-0.013 * * *$ & -0.002 \\
Male & $(0.002)$ & $(0.002)$ & $(0.002)$ & $(0.003)$ & $(0.003)$ & $(0.001)$ \\
& $0.061^{* *}$ & $0.048^{*}$ & 0.013 & -0.022 & -0.017 & -0.004 \\
& $(0.030)$ & $(0.027)$ & $(0.008)$ & $(0.044)$ & $(0.037)$ & $(0.019)$
\end{tabular}




$\begin{array}{lcccccc}\text { Rank } & -0.004 & -0.001 & 0.000 & -0.024^{* *} & -0.028^{* * *} & 0.002 \\ & (0.005) & (0.006) & (0.002) & (0.009) & (0.008) & (0.007) \\ \text { Earnings in last round } & -0.000 & -0.000^{*} & 0.000 & -0.001^{* * *} & -0.001^{* *} & -0.001^{* * *} \\ & (0.000) & (0.000) & (0.000) & (0.000) & (0.000) & (0.000) \\ \text { Attacked in last round } & 0.046^{* *} & 0.020 & 0.021 & -0.008 & -0.009 & 0.001 \\ & (0.019) & (0.018) & (0.021) & (0.038) & (0.022) & (0.031) \\ \text { Constant } & 0.208^{* * *} & 0.154^{* *} & 0.037^{*} & 0.427^{* * *} & 0.366^{* * *} & 0.068^{* *} \\ & (0.064) & (0.070) & (0.021) & (0.063) & (0.059) & (0.028)\end{array}$

Observations

1,850

Number of Subjects

185

Note: Estimates from Random effects regressions with standard errors, clustered at the group level, in parentheses. Columns 1 to 3 restrict the sample to HI only while columns 4 to 6 restrict the sample to LI. Dependent Variable: (columns 1-4) Attacks directed towards player $\mathrm{j}$; (columns 2-5) Attacks directed towards HI (columns 3-6) Attacks directed towards LI. $\mathrm{p}<0.01, * * \mathrm{p}<0.05, * \mathrm{p}<0.1$

Table 8: Random effects regression, the impact of initial income assignment, Stage 2, periods 1-10.

\begin{tabular}{llll}
\hline & $(1)$ & $(2)$ & $(3)$ \\
& Attack & Attack HI & Attack LI \\
\hline Luck/Mobility & $-0.110^{* * *}$ & $-0.110^{* * *}$ & 0.000 \\
Effort/Mobility & $(0.038)$ & $(0.035)$ & $(0.010)$ \\
Effort/Immobility & -0.040 & -0.057 & 0.016 \\
& $(0.039)$ & $(0.037)$ & $(0.014)$ \\
HI Type & 0.038 & -0.001 & $0.039 * * *$ \\
Period Trend & $(0.056)$ & $(0.049)$ & $(0.013)$ \\
Male & -0.044 & -0.061 & 0.009 \\
Rank & $(0.040)$ & $(0.039)$ & $(0.021)$ \\
Earnings in last round & $-0.010 * * *$ & $-0.008 * * *$ & $-0.003 * * *$ \\
Attacked in last round & $(0.002)$ & $(0.002)$ & $(0.001)$ \\
Constant & 0.021 & 0.017 & 0.004 \\
& $(0.024)$ & $(0.022)$ & $(0.010)$ \\
& $-0.014 * *$ & $-0.014 * * *$ & -0.001 \\
& $(0.006)$ & $(0.005)$ & $(0.003)$ \\
& $-0.000^{* *}$ & $-0.000^{* *}$ & -0.000 \\
& $(0.000)$ & $(0.000)$ & $(0.000)$ \\
& $0.035^{* *}$ & 0.016 & 0.018 \\
& $(0.018)$ & $(0.016)$ & $(0.019)$ \\
& $0.325 * * *$ & $0.312 * * *$ & 0.026 \\
& $(0.057)$ & $(0.053)$ & $(0.033)$
\end{tabular}


Panel B: Difference Estimates

$\begin{array}{llll}\text { Effort/Mobility - Effort/Immobility } & -0.079 * & -0.055 & -0.023 \\ & (0.045) & (0.041) & (0.015) \\ \text { Effort/Mobility - Luck/Mobility } & 0.069 * * & 0.054 * * & 0.016 \\ & (0.025) & (0.024) & (0.012) \\ & & & \\ \text { Observations } & 3,700 & 3,700 & 3,700 \\ \text { No. of Subjects } & 370 & 370 & 370\end{array}$

Note: Estimates from Random effects regressions with standard errors, clustered at the group level, in parentheses. Panel B uses post-estimation linear combination tests of hypotheses using $t$-tests $* * * \mathrm{p}<0.01, * * \mathrm{p}<0.05, * \mathrm{p}<0.1$

Table 9A: Summary stats, heterogeneity, Stage 2, periods $1-10$.

\begin{tabular}{lllllll}
\hline & & \multicolumn{5}{c}{ Differences } \\
& $(1)$ & $(2)$ & $(3)$ & $(4)$ & $(5)$ & $(6)$ \\
& Luck/ & Luck/Luc & Luck/Effor & & \\
& Immobility & $\mathrm{k}$ & $\mathrm{t}$ & $(1-2)$ & $(1-3)$ & $(2-3)$ \\
\hline & 0.171 & 0.072 & 0.042 & 0.099 & 0.129 & 0.030 \\
Attacking & $(0.035)$ & $(0.072)$ & $(0.022)$ & {$[\mathbf{0 . 0 5 5}]$} & {$[\mathbf{0 . 0 0 7}]$} & {$[0.137]$} \\
& 0.134 & 0.072 & 0.048 & 0.062 & 0.087 & 0.024 \\
Attacking by HI & $(0.034)$ & $(0.030)$ & $(0.038)$ & {$[0.189]$} & {$[\mathbf{0 . 0 4 1}]$} & {$[0.341]$} \\
& 0.209 & 0.072 & 0.036 & 0.137 & 0.172 & 0.036 \\
Attacking by LI & $(0.209)$ & $(0.022)$ & $(0.026)$ & {$[0.163]$} & {$[\mathbf{0 . 0 9 7}]$} & {$[0.460]$} \\
& 0.157 & 0.056 & 0.032 & 0.101 & 0.125 & 0.024 \\
Attacks towards HI & $(0.035)$ & $(0.018)$ & $(0.020)$ & {$[\mathbf{0 . 0 4 5}]$} & {$[\mathbf{0 . 0 0 7}]$} & {$[0.122]$} \\
Attacks towards LI & 0.014 & 0.0160 & 0.010 & -0.002 & 0.004 & 0.006 \\
Attacks by HI towards HI & $(0.008)$ & $(0.007)$ & $(0.004)$ & {$[0.635]$} & {$[0.946]$} & {$[0.669]$} \\
& 0.111 & 0.052 & 0.032 & 0.059 & 0.079 & 0.020 \\
Attacks by HI towards LI & $(0.029)$ & $(0.031)$ & $(0.032)$ & {$[0.219]$} & {$[\mathbf{0 . 0 7 7}]$} & {$[0.344]$} \\
& 0.023 & 0.020 & 0.016 & 0.003 & 0.007 & 0.004 \\
Attacks by LI towards HI & $(0.017)$ & $(0.0126)$ & $(0.007)$ & {$[0.927]$} & {$[0.931]$} & {$[1.00]$} \\
Attacks by LI towards LI & $(0.203$ & 0.060 & 0.032 & 0.143 & 0.171 & 0.028 \\
& $(0.004)$ & $(0.008)$ & $(0.004)$ & {$[0.558]$} & {$[0.914]$} & {$[0.520]$} \\
\hline
\end{tabular}

Table 9B: Summary stats, heterogeneity, Stage 2, periods $1-10$.

\begin{tabular}{lllllll}
\hline & \multicolumn{3}{c}{ Means } & \multicolumn{3}{c}{ Differences } \\
& $(1)$ & $(2)$ & $(3)$ & $(4)$ & $(5)$ & $(6)$ \\
& Effort/ & Effort/Luc & Effort/ & & & \\
& Immobility & $\mathrm{k}$ & Effort & $(7-8)$ & $(7-9)$ & $(8-9)$ \\
\hline Attacking & 0.211 & 0.138 & 0.119 & 0.074 & 0.092 & 0.018 \\
\hline
\end{tabular}




\begin{tabular}{lllllll}
\hline & $(0.038)$ & $(0.033)$ & $(0.027)$ & {$[0.244]$} & {$[0.187]$} & {$[0.896]$} \\
& 0.200 & 0.085 & 0.129 & 0.115 & 0.071 & -0.044 \\
Attacking by HI & $(0.054)$ & $(0.029)$ & $(0.049)$ & {$[0.157]$} & {$[0.385]$} & {$[0.410]$} \\
& 0.222 & 0.190 & 0.110 & 0.032 & 0.113 & 0.081 \\
Attacking by LI & $(0.058)$ & $(0.054)$ & $(0.029)$ & {$[0.679]$} & {$[0.317]$} & {$[0.361]$} \\
& 0.157 & 0.095 & 0.103 & 0.062 & 0.053 & -0.008 \\
Attacks towards HI & $(0.033)$ & $(0.026)$ & $(0.026)$ & {$[0.259]$} & {$[0.413]$} & {$[0.740]$} \\
& 0.054 & 0.015 & 0.016 & 0.012 & 0.039 & 0.026 \\
Attacks towards LI & $(0.015)$ & $(0.023)$ & $(0.005)$ & {$[0.200]$} & {$[0.103]$} & {$[0.804]$} \\
& 0.160 & 0.075 & 0.113 & 0.084 & 0.047 & -0.038 \\
Attacks by HI towards HI & $(0.052)$ & $(0.029)$ & $(0.047)$ & {$[0.172]$} & {$[0.638]$} & {$[0.647]$} \\
& 0.040 & 0.010 & 0.016 & 0.030 & 0.024 & -0.006 \\
Attacks by HI towards LI & $(0.016)$ & $(0.007)$ & $(0.004)$ & {$[0.200]$} & {$[0.631]$} & {$[0.211]$} \\
& 0.153 & 0.115 & 0.094 & 0.038 & 0.060 & 0.022 \\
Attacks by LI towards HI & $(0.045)$ & $(0.044)$ & $(0.029)$ & {$[0.811]$} & {$[0.688]$} & {$[0.926]$} \\
& 0.069 & 0.075 & 0.016 & -0.006 & 0.053 & 0.059 \\
Attacks by LI towards LI & $(0.025)$ & $(0.043)$ & $(0.010)$ & {$[0.630]$} & {$[0.116]$} & {$[0.481]$} \\
\hline
\end{tabular}

Note: Standard errors reported in brackets. P-values from Wilcoxon Rank Sum reported in square brackets.

Table 10: Random effect regression, Stage 2, periods 1-10, heterogeneity analysis

\begin{tabular}{llll}
\hline & $(1)$ & $(2)$ & $(3)$ \\
& Attack & Attack HI & Attack LI \\
\hline Panel A & & & \\
Effort/Immobility & 0.038 & -0.001 & $0.039^{* * *}$ \\
& $(0.056)$ & $(0.049)$ & $(0.013)$ \\
Luck/Luck & $-0.094^{* *}$ & $-0.098^{* * *}$ & 0.003 \\
& $(0.038)$ & $(0.034)$ & $(0.011)$ \\
Effort/Luck & -0.034 & -0.061 & 0.028 \\
& $(0.046)$ & $(0.044)$ & $(0.021)$ \\
Luck/Effort & $-0.125^{* * *}$ & $-0.123^{* * *}$ & -0.002 \\
& $(0.044)$ & $(0.041)$ & $(0.010)$ \\
Effort/Effort & -0.049 & -0.051 & 0.003 \\
& $(0.040)$ & $(0.037)$ & $(0.009)$ \\
LI Subject & -0.044 & -0.061 & 0.009 \\
Period Trend & $(0.040)$ & $(0.039)$ & $(0.021)$ \\
& $-0.010^{* * *}$ & $-0.008^{* * *}$ & $-0.003 * * *$ \\
Male & $(0.002)$ & $(0.002)$ & $(0.001)$ \\
& 0.022 & 0.019 & 0.004 \\
& $(0.024)$ & $(0.022)$ & $(0.010)$
\end{tabular}




\begin{tabular}{llll} 
Rank & $-0.014^{* *}$ & $-0.014^{* * *}$ & -0.001 \\
Earnings in last round & $(0.006)$ & $(0.005)$ & $(0.003)$ \\
& $-0.000^{* *}$ & $-0.000^{* *}$ & -0.000 \\
Attacked in last round & $(0.000)$ & $(0.000)$ & $(0.000)$ \\
& $0.035^{* *}$ & 0.016 & 0.018 \\
Constant & $(0.018)$ & $(0.016)$ & $(0.019)$ \\
& $0.325^{* * *}$ & $0.311^{* * *}$ & 0.026 \\
& $(0.056)$ & $(0.053)$ & $(0.033)$ \\
\hline Panel B: Difference Estimates & & & \\
\hline Luck/Luck - Luck/Effort & & & \\
Effort/Immobility - Effort/Luck & 0.031 & 0.025 & 0.006 \\
& $(0.030)$ & $(0.027)$ & $(0.007)$ \\
Effort/Immobility - Effort/Effort & 0.072 & 0.060 & 0.012 \\
& $(0.053)$ & $(0.047)$ & $(0.021)$ \\
Effort/Luck - Effort/Effort & $0.087^{*}$ & 0.050 & $0.037 * *$ \\
& $(0.048)$ & $(0.041)$ & $(0.010)$ \\
& 0.015 & -0.010 & 0.025 \\
Observations & $(0.036)$ & $(0.036)$ & $(0.019)$ \\
No. of Subjects & & & \\
\hline
\end{tabular}

Note: Estimates from Random effects regressions with standard errors, clustered at the group level, in parentheses. The treatments are reported as $\mathrm{a} / \mathrm{b}$ where a represents the method of initial endowment and $\mathrm{b}$ the mobility mechanism. Dependent Variable: (1) Attacks directed towards player j; (2) Attacks directed towards HI types; (3) Attacks directed towards LI types. Panel A presents coefficients of Random effects regressions; Panel B uses post-estimation linear combination tests of hypotheses using $t$-tests. ${ }^{* * *} p<0.01,{ }^{* *} p<0.05,{ }^{*} p<0.1$ 

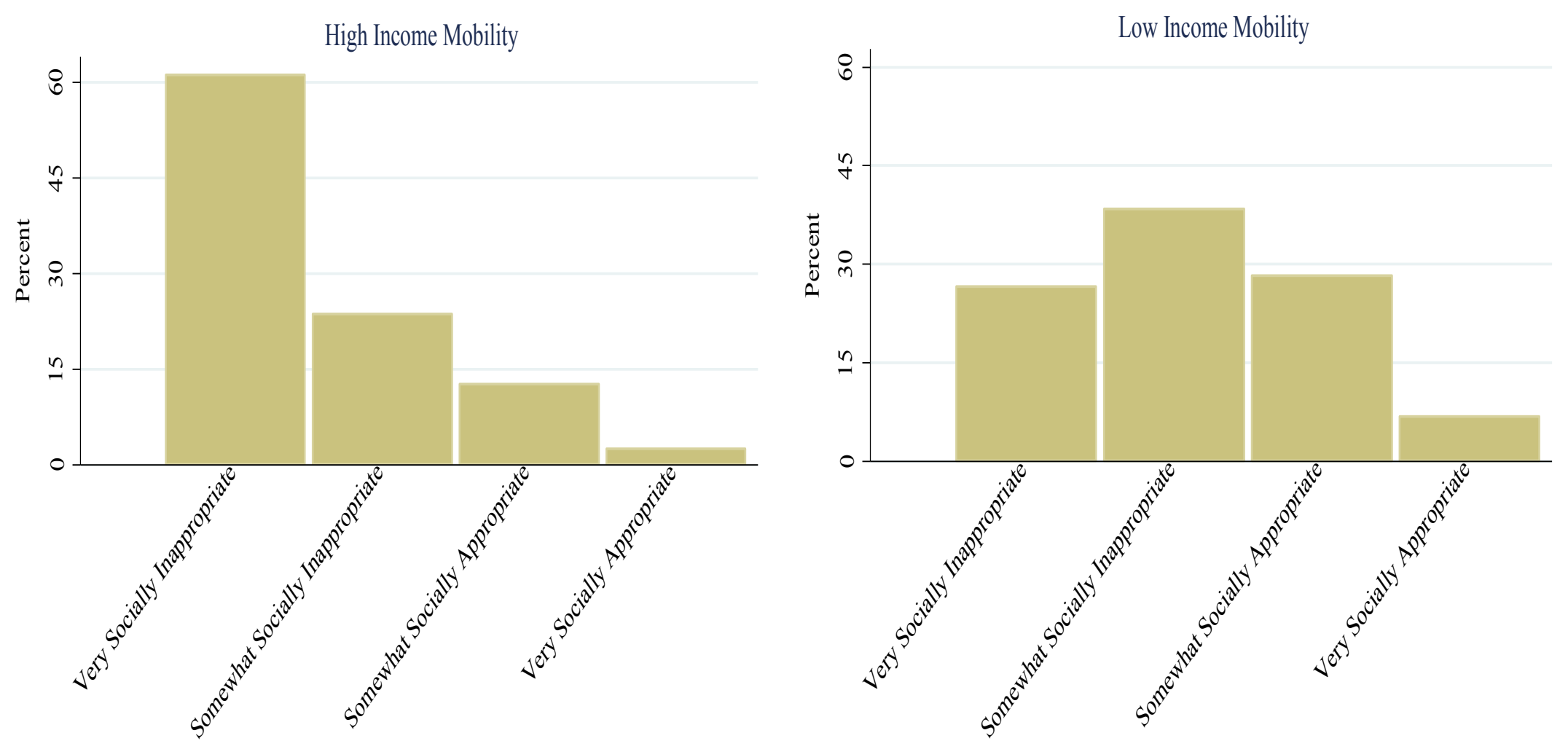

Figure 1: The social appropriateness of antisocial behaviour under low income mobility (left) and high income mobility (right) 


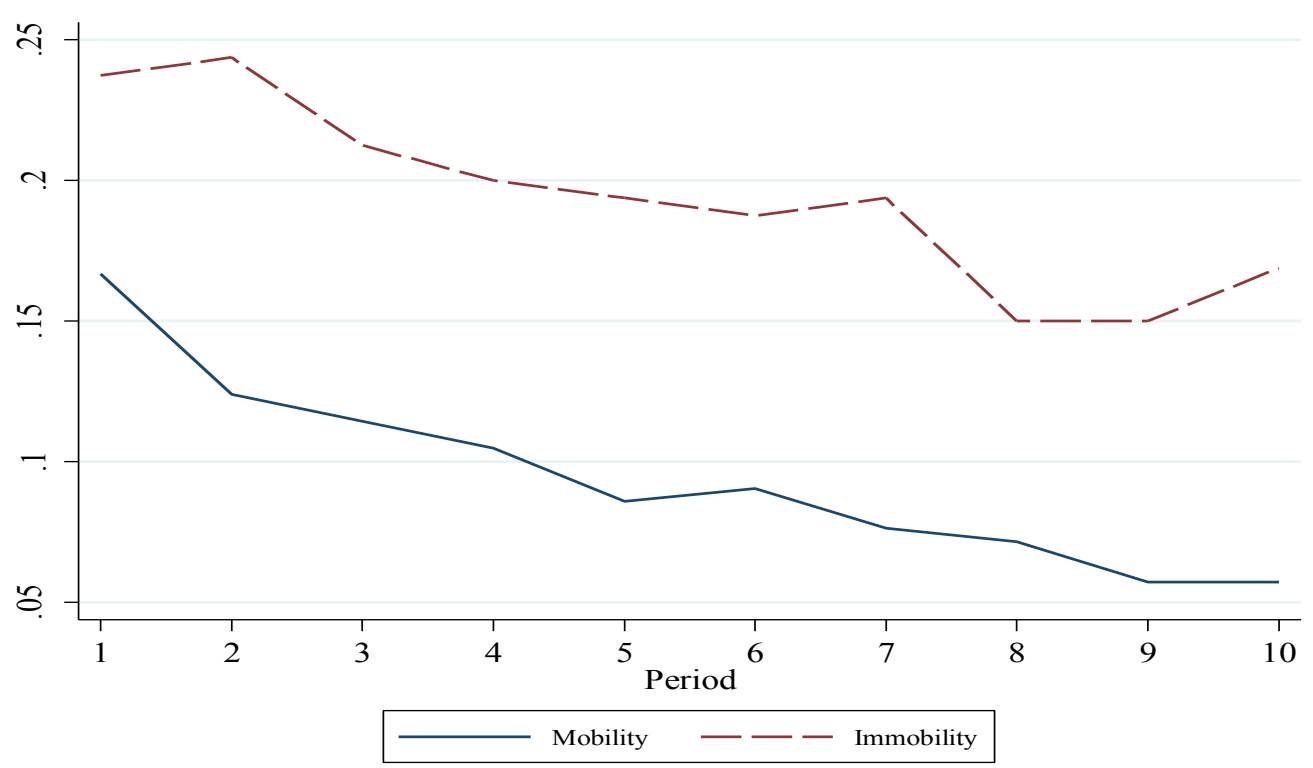

Panel A

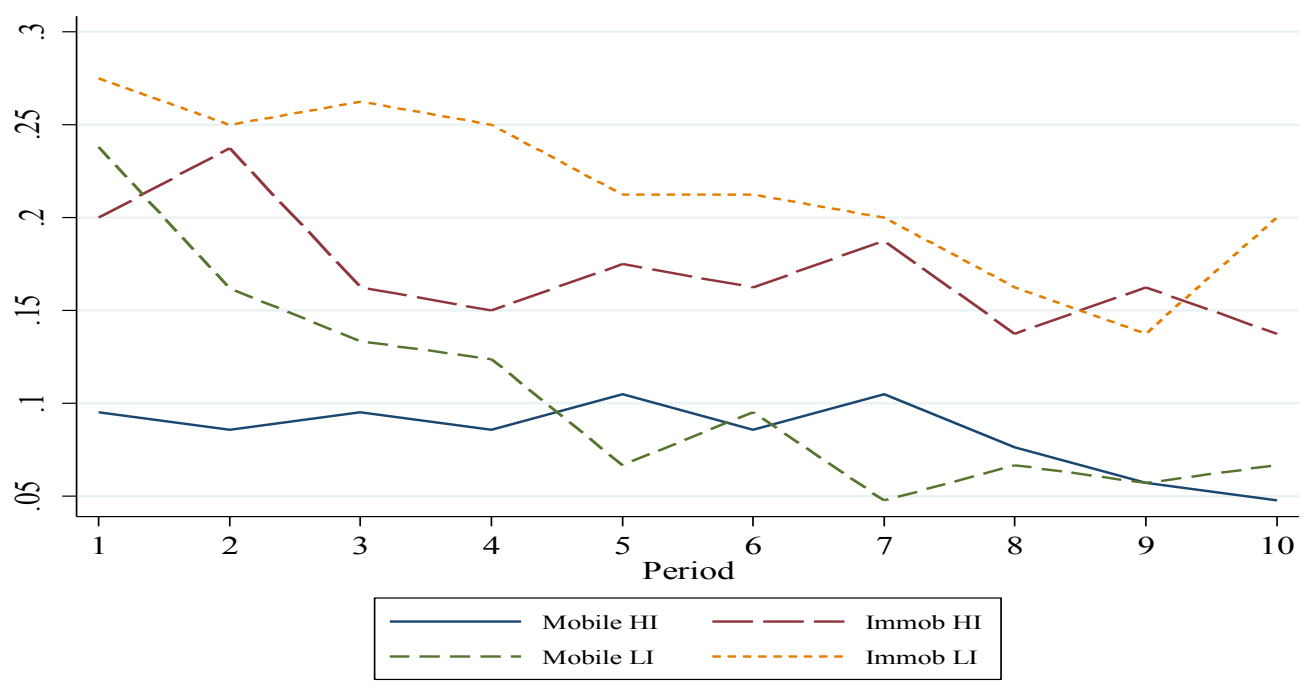

Panel B

Figure 2: The impact of mobility on antisocial behaviour over time. Panel A compares mobility to immobility treatments; Panel B illustrates antisocial behaviour in mobility and immobility by income type. 

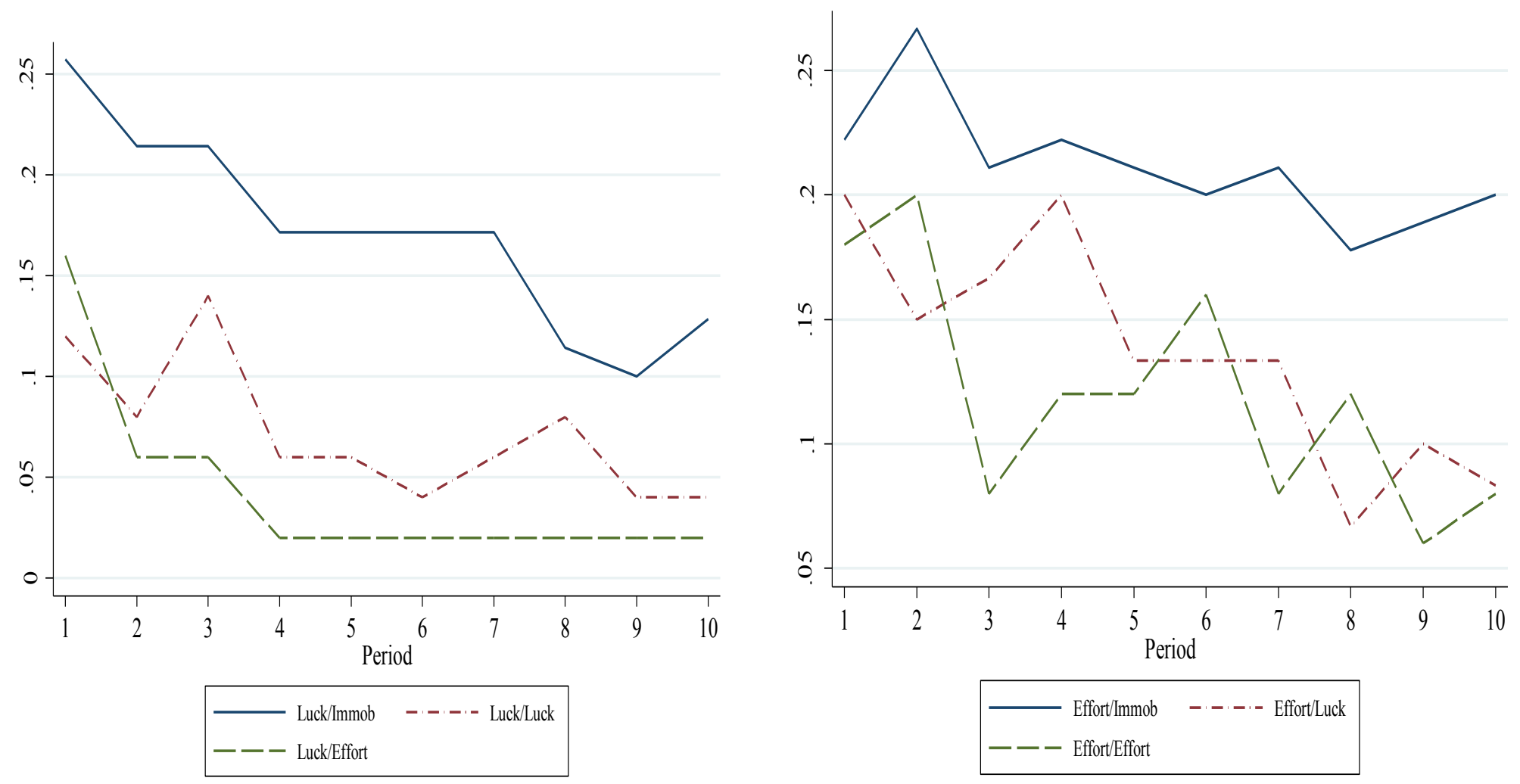

Panel A

Panel B

Figure 3: The impact of mobility on antisocial behavior by treatment, Stage 2, periods 1-10. Panel A illustrates antisocial behaviour when initial income is assigned by luck; Panel B shows antisocial behaviour when initial income is assigned by effort 


\section{Appendix A1}

Table A1: Attempting income change. Rates of antisocial behaviour between those who attempt to change and those who do not attempt to change.

\begin{tabular}{|c|c|c|c|}
\hline Variable & $\begin{array}{l}\text { Attempt income } \\
\text { change }\end{array}$ & $\begin{array}{l}\text { Do not attempt } \\
\text { income change }\end{array}$ & Difference \\
\hline \multicolumn{4}{|l|}{ Panel A: Stage 2, periods } \\
\hline Attacks by LI & $\begin{array}{l}0.101 \\
(0.027)\end{array}$ & $\begin{array}{l}0.091 \\
(.081)\end{array}$ & $\begin{array}{l}0.010 \\
{[0.406]}\end{array}$ \\
\hline Attacks towards HI & $\begin{array}{l}0.063 \\
(0.018)\end{array}$ & $\begin{array}{l}0.078 \\
(0.017)\end{array}$ & $\begin{array}{l}0.014 \\
{[0.472]}\end{array}$ \\
\hline Attacks towards LI & $\begin{array}{l}0.038 \\
(0.018)\end{array}$ & $\begin{array}{l}0.014 \\
(0.004)\end{array}$ & $\begin{array}{l}0.024 \\
{[0.828]}\end{array}$ \\
\hline Attacks by LI towards HI & $\begin{array}{l}0.060 \\
(0.019)\end{array}$ & $\begin{array}{l}0.075 \\
(0.033)\end{array}$ & $\begin{array}{l}0.015 \\
{[0.541]}\end{array}$ \\
\hline Attacks by LI towards LI & $\begin{array}{l}0.021 \\
(0.012)\end{array}$ & $\begin{array}{l}0.009 \\
(0.003)\end{array}$ & $\begin{array}{l}0.013 \\
{[0.802]}\end{array}$ \\
\hline $\begin{array}{l}\text { Panel B: Stage 2, periods } \\
11-20\end{array}$ & $\begin{array}{l}\text { Attempt income } \\
\text { change }\end{array}$ & $\begin{array}{l}\text { Do not attempt } \\
\text { income change }\end{array}$ & Difference \\
\hline Attacks & $\begin{array}{l}0.047 \\
(0.018)\end{array}$ & $\begin{array}{l}0.053 \\
(0.015)\end{array}$ & $\begin{array}{l}0.007 \\
{[0.641]}\end{array}$ \\
\hline Attacks towards HI & $\begin{array}{l}0.039 \\
(0.016)\end{array}$ & $\begin{array}{l}0.049 \\
(0.015)\end{array}$ & $\begin{array}{l}0.009 \\
{[0.822]}\end{array}$ \\
\hline Attacks towards LI & $\begin{array}{l}0.007 \\
(0.005)\end{array}$ & $\begin{array}{l}0.004 \\
(0.002)\end{array}$ & $\begin{array}{l}0.003 \\
{[0.992]}\end{array}$ \\
\hline Attacks by LI & $\begin{array}{l}0.055 \\
(0.023)\end{array}$ & $\begin{array}{l}0.053 \\
(0.031)\end{array}$ & $\begin{array}{l}0.002 \\
{[0.878]}\end{array}$ \\
\hline Attacks by LI towards HI & $\begin{array}{l}0.046 \\
(0.021)\end{array}$ & $\begin{array}{l}0.047 \\
(0.031)\end{array}$ & $\begin{array}{l}0.002 \\
{[0.912]}\end{array}$ \\
\hline Attacks by LI towards LI & $\begin{array}{l}0.009 \\
(0.006)\end{array}$ & $\begin{array}{l}0.006 \\
(0.004)\end{array}$ & $\begin{array}{l}0.003 \\
{[0.933]}\end{array}$ \\
\hline $\begin{array}{l}\text { Panel C: Stage 2, } \\
\text { periods } 11-20\end{array}$ & $\begin{array}{l}\text { Attempt income } \\
\text { change Succeed }\end{array}$ & $\begin{array}{l}\text { Attempt income } \\
\text { change don't } \\
\text { succeed }\end{array}$ & Difference \\
\hline Attack & $\begin{array}{l}0.013 \\
(0.009)\end{array}$ & $\begin{array}{l}0.056 \\
(0.023)\end{array}$ & $\begin{array}{l}0.044 \\
{[0.645]}\end{array}$ \\
\hline Attacks towards HI & $\begin{array}{l}0.013 \\
(0.009)\end{array}$ & $\begin{array}{l}0.047 \\
(0.021)\end{array}$ & $\begin{array}{l}0.035 \\
{[0.905]}\end{array}$ \\
\hline Attacks towards LI & $\begin{array}{l}0.00 \\
(0.00)\end{array}$ & $\begin{array}{l}0.009 \\
(0.005)\end{array}$ & $\begin{array}{l}0.009 \\
{[0.343]}\end{array}$ \\
\hline
\end{tabular}


Note: Square brackets report p-values from a Wilcoxon Rank Sum test. The sample is restricted to LI types in the mobility set of treatments. Panel C, column 1 refers to LI subjects who attempted to change their income and succeeded while the second column refers to those LI who attempted but where not successful at changing their income type.

Table A2: Antisocial behaviour, mobility versus immobility Stage 2, periods $11-20$

\begin{tabular}{llll}
\hline Variable & Mobility & Immobility & Diff \\
\hline \multirow{2}{*}{ Attacks } & 0.051 & & \\
Attacks by HI & $(0.012)$ & 0.138 & 0.086 \\
& 0.049 & $(.024)$ & {$[\mathbf{0 . 0 0 4}]$} \\
Attacks by LI & $(0.013)$ & 0.118 & 0.069 \\
& 0.054 & $(0.028)$ & {$[\mathbf{0 . 0 9 0}]$} \\
Attacks towards HI & $(0.019)$ & 0.158 & 0.103 \\
Attacks towards LI & 0.045 & $(0.041)$ & {$[\mathbf{0 . 0 1 5}]$} \\
& $(0.011)$ & 0.100 & 0.055 \\
Attacks by HI towards HI & 0.006 & $(0.018)$ & {$[\mathbf{0 . 0 1 0}]$} \\
Attacks by LI towards HI & 0.045 & 0.038 & 0.032 \\
& $(0.014)$ & $(0.015)$ & {$[\mathbf{0 . 0 0 8}]$} \\
Attacks by HI towards LI & 0.004 & 0.096 & 0.051 \\
& $(0.017)$ & $(0.025)$ & {$[0.172]$} \\
Attacks by LI towards LI & 0.008 & 0.104 & 0.058 \\
& $(0.004)$ & $(0.027)$ & {$[\mathbf{0 . 0 2 5}]$} \\
& 0.021 & 0.018 \\
& & $(0.007)$ & {$[\mathbf{0 . 0 4 0}]$} \\
& 0.054 & 0.045 \\
& $(0.028)$ & {$[\mathbf{0 . 0 7 8}]$}
\end{tabular}

Note: Square brackets report p-values from a Wilcoxon Rank Sum test. The sample restricted to periods $11-20$ of stage 2 . 
Table A3: Random effects, antisocial behaviour, Stage 2, periods 11-20.

\begin{tabular}{|c|c|c|c|}
\hline & (1) & (2) & (3) \\
\hline & Attack & Attack HI & Attack LI \\
\hline \multirow[t]{2}{*}{ Mobility } & $-0.086 * * *$ & $-0.055^{* *}$ & $-0.031 * *$ \\
\hline & $(0.030)$ & $(0.022)$ & $(0.014)$ \\
\hline \multirow[t]{2}{*}{ LI Subject } & -0.041 & -0.045 & 0.007 \\
\hline & $(0.026)$ & $(0.032)$ & $(0.015)$ \\
\hline \multirow[t]{2}{*}{ Period Trend } & -0.001 & -0.001 & 0.000 \\
\hline & $(0.002)$ & $(0.001)$ & $(0.001)$ \\
\hline \multirow[t]{2}{*}{ Male } & $0.047 *$ & $0.034 *$ & 0.013 \\
\hline & $(0.025)$ & $(0.018)$ & $(0.011)$ \\
\hline \multirow[t]{2}{*}{ Rank } & $-0.013 * *$ & -0.010 & -0.003 \\
\hline & $(0.006)$ & $(0.006)$ & $(0.002)$ \\
\hline \multirow[t]{2}{*}{ Earnings in last round } & 0.000 & -0.000 & $0.000 *$ \\
\hline & $(0.000)$ & $(0.000)$ & $(0.000)$ \\
\hline \multirow[t]{2}{*}{ Attacked in last round } & $0.028 * *$ & 0.022 & 0.009 \\
\hline & $(0.013)$ & $(0.014)$ & $(0.006)$ \\
\hline \multirow[t]{2}{*}{ Constant } & $0.216^{* * *}$ & $0.181 * * *$ & 0.031 \\
\hline & $(0.062)$ & $(0.060)$ & $(0.022)$ \\
\hline \multirow[t]{2}{*}{ Observations } & 3,700 & 3,700 & 3,700 \\
\hline & 370 & 370 & 370 \\
\hline
\end{tabular}

Note: Estimates from Random effects regressions with standard errors, clustered at the group level, in parentheses. Column 1 reports attacks directed towards player j; Column 2 (3) reports Attacks directed towards HI (LI). The sample restricted to periods $11-20$ of stage 2 . *** $\mathrm{p}<0.01$, $* * \mathrm{p}<0.05, * \mathrm{p}<0.1$ 
Table A4: Random effects regression, antisocial behaviour, Stage 2, periods 11-20, by subject type.

\begin{tabular}{lllllll}
\hline \multicolumn{4}{l}{ Type HI Only } & \multicolumn{4}{l}{ Type LI Only } \\
& $(1)$ & $(2)$ & $(3)$ & $(4)$ & $(5)$ & $(6)$ \\
& Attack & Attack HI & Attack LI & Attack & Attack HI & Attack LI \\
\hline \multirow{3}{*}{ Mobility } & & & & & & \\
& $-0.072^{* *}$ & $-0.053^{*}$ & $-0.018^{* *}$ & $-0.106^{* *}$ & $-0.060^{*}$ & $-0.045^{*}$ \\
Period Trend & $(0.031)$ & $(0.030)$ & $(0.007)$ & $(0.043)$ & $(0.032)$ & $(0.027)$ \\
& 0.000 & 0.000 & 0.000 & -0.003 & -0.003 & 0.001 \\
Male & $(0.002)$ & $(0.002)$ & $(0.001)$ & $(0.003)$ & $(0.002)$ & $(0.001)$ \\
& $0.066^{* * *}$ & $0.059^{* *}$ & 0.007 & 0.017 & 0.001 & 0.016 \\
Rank & $(0.025)$ & $(0.025)$ & $(0.007)$ & $(0.043)$ & $(0.028)$ & $(0.025)$ \\
& -0.003 & -0.003 & -0.001 & $-0.029^{* * *}$ & $-0.022^{* *}$ & $-0.006^{*}$ \\
Earnings in last round & $(0.006)$ & $(0.006)$ & $(0.001)$ & $(0.010)$ & $(0.009)$ & $(0.004)$ \\
Attacked in last round & 0.000 & -0.000 & $0.000^{*}$ & -0.000 & -0.000 & 0.000 \\
& $(0.000)$ & $(0.000)$ & $(0.000)$ & $(0.000)$ & $(0.000)$ & $(0.000)$ \\
Constant & 0.025 & 0.017 & 0.009 & 0.032 & 0.032 & 0.006 \\
& $(0.018)$ & $(0.018)$ & $(0.008)$ & $(0.024)$ & $(0.035)$ & $(0.030)$ \\
Observations & 0.094 & 0.088 & 0.009 & $0.278^{* * *}$ & $0.219^{* * *}$ & 0.053 \\
Number of subjects & $(0.061)$ & $(0.066)$ & $(0.018)$ & $(0.059)$ & $(0.050)$ & $(0.034)$
\end{tabular}

Note: Estimates from Random effects regressions with standard errors, clustered at the group level, in parentheses. The treatments are reported as a/b where a represents the method of initial endowment and $b$ the mobility mechanism. Columns 1 to 3 restrict the sample to HI only while columns 4 to 6 restrict the sample to LI. Dependent Variable: $(1,4)$ Attacks directed towards player j; $(2,5)$ Attacks directed towards HI $(3,6)$ Attacks directed towards LI. The sample restricted to periods $11-20$ of stage $2 . * * * \mathrm{p}<0.01, * * \mathrm{p}<0.05, * \mathrm{p}<0.1$ 
Table A5: Random effects regression, heterogeneity analysis, Stage 2, periods $11-20$.

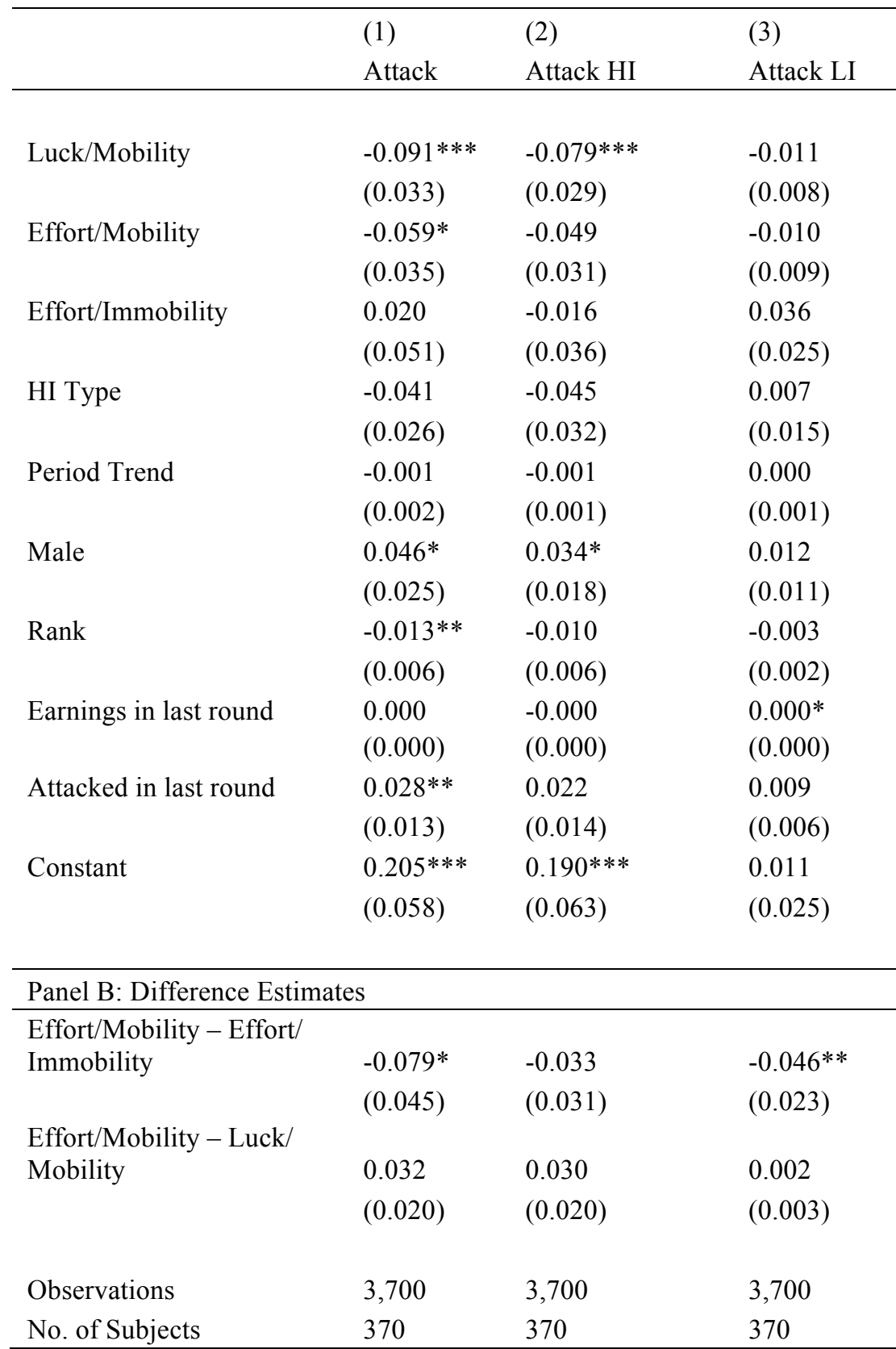

Note: Estimates from Random effects regressions with standard errors, clustered at the group level, in parentheses. The treatments are reported as $\mathrm{a} / \mathrm{b}$ where a represents the method of initial endowment and $\mathrm{b}$ the mobility mechanism. Column 1 reports attacks directed towards player j; Column 2 (3) reports Attacks directed towards HI (LI). Panel A presents coefficients of Random effects regressions. Panel B uses post-estimation linear combination tests of hypotheses using $t$-tests. The sample restricted to periods $11-20$ of stage $2 .{ }^{* * *} \mathrm{p}<0.01,{ }^{* *}$ $\mathrm{p}<0.05, * \mathrm{p}<0.1$ 
Table A6: Random effect regression, heterogeneity analysis, by income group, Stage 2, periods 11-20

\begin{tabular}{|c|c|c|c|}
\hline & (1) & (2) & (3) \\
\hline & Attack & Attack HI & Attack LI \\
\hline \multirow[t]{2}{*}{ Effort/Immobility } & 0.020 & -0.016 & $0.036^{* *}$ \\
\hline & $(0.051)$ & $(0.036)$ & $(0.015)$ \\
\hline \multirow[t]{2}{*}{ Luck/Luck } & $-0.078 * *$ & $-0.067 * *$ & -0.011 \\
\hline & $(0.033)$ & $(0.030)$ & $(0.008)$ \\
\hline \multirow[t]{2}{*}{ Effort/Luck } & -0.061 & -0.052 & -0.008 \\
\hline & $(0.041)$ & $(0.037)$ & $(0.010)$ \\
\hline \multirow[t]{2}{*}{ Luck/Effort } & $-0.105 * * *$ & $-0.092 * * *$ & -0.012 \\
\hline & $(0.035)$ & $(0.031)$ & $(0.009)$ \\
\hline \multirow[t]{2}{*}{ Effort/Effort } & -0.057 & -0.045 & -0.012 \\
\hline & $(0.035)$ & $(0.031)$ & $(0.008)$ \\
\hline \multirow[t]{2}{*}{ LI Subject } & -0.043 & -0.047 & 0.007 \\
\hline & $(0.027)$ & $(0.032)$ & $(0.015)$ \\
\hline \multirow[t]{2}{*}{ Period Trend } & -0.001 & -0.001 & 0.000 \\
\hline & $(0.002)$ & $(0.001)$ & $(0.001)$ \\
\hline \multirow[t]{2}{*}{ Male } & $0.047 *$ & $0.035^{*}$ & 0.012 \\
\hline & $(0.024)$ & $(0.018)$ & $(0.011)$ \\
\hline \multirow[t]{2}{*}{ Rank } & $-0.013 * *$ & -0.010 & -0.003 \\
\hline & $(0.006)$ & $(0.006)$ & $(0.002)$ \\
\hline \multirow[t]{2}{*}{ Earnings in last round } & 0.000 & -0.000 & $0.000^{*}$ \\
\hline & $(0.000)$ & $(0.000)$ & $(0.000)$ \\
\hline \multirow[t]{2}{*}{ Attacked in last round } & $0.028^{* *}$ & 0.022 & 0.009 \\
\hline & $(0.013)$ & $(0.014)$ & $(0.006)$ \\
\hline \multirow[t]{2}{*}{ Constant } & $0.206 * * *$ & $0.191 * * *$ & 0.011 \\
\hline & $(0.058)$ & $(0.063)$ & $(0.025)$ \\
\hline \multicolumn{4}{|l|}{ Panel B: Difference Estimates } \\
\hline \multirow[t]{2}{*}{ Luck/Luck - Luck/Effort } & 0.027 & 0.025 & 0.001 \\
\hline & $(0.021)$ & $(0.021)$ & $(0.004)$ \\
\hline \multirow[t]{2}{*}{ Effort/Immobility - Effort/Luck } & 0.081 & 0.037 & $0.044^{*}$ \\
\hline & $(0.050)$ & $(0.037)$ & $(0.024)$ \\
\hline \multirow{2}{*}{ Effort/Immobility - Effort/Effort } & $0.077^{*}$ & 0.029 & $0.048 * *$ \\
\hline & $(0.045)$ & $(0.031)$ & $(0.023)$ \\
\hline \multirow{2}{*}{ Effort/Luck - Effort/Effort } & -0.004 & -0.007 & 0.004 \\
\hline & $(0.004)$ & $(0.031)$ & $(0.006)$ \\
\hline Observations & 3,700 & 3,700 & 3,700 \\
\hline No. of Subjects & 370 & 370 & 370 \\
\hline
\end{tabular}


Note: Estimates from Random effects regressions with standard errors, clustered at the group level, in parentheses. The treatments are reported as $\mathrm{a} / \mathrm{b}$ where a represents the method of initial endowment and $\mathrm{b}$ the mobility mechanism. Column 1 reports attacks directed towards $\mathrm{j}$; Column 2 (3) reports attacks directed towards HI (LI). Panel A presents coefficients of Random effects regressions. Panel B uses post-estimation linear combination tests of hypotheses using $t$-tests. The sample restricted to periods $11-20$ of stage 2 . $* * * \mathrm{p}<0.01,{ }^{*} * \mathrm{p}<0.05, * \mathrm{p}<0.1$ 
Table A7: Random effect regression, heterogeneity analysis, by income group, Stage 2, periods 11-20

\begin{tabular}{|c|c|c|c|c|c|c|}
\hline & \multicolumn{3}{|c|}{ HI Only } & \multicolumn{3}{|c|}{ LI Only } \\
\hline & (1) & (2) & (3) & (4) & (5) & (6) \\
\hline & Attack & Attack HI & Attack LI & Attack & Attack HI & Attack LI \\
\hline Effort Immobility & $\begin{array}{l}0.026 \\
(0.051)\end{array}$ & $\begin{array}{l}0.013 \\
(0.048)\end{array}$ & $\begin{array}{l}0.013 \\
(0.013)\end{array}$ & $\begin{array}{l}0.014 \\
(0.079)\end{array}$ & $\begin{array}{l}-0.046 \\
(0.056)\end{array}$ & $\begin{array}{l}0.060 \\
(0.050)\end{array}$ \\
\hline Luck/Luck & $\begin{array}{l}-0.026 \\
(0.044)\end{array}$ & $\begin{array}{l}-0.021 \\
(0.045)\end{array}$ & $\begin{array}{l}-0.005 \\
(0.011)\end{array}$ & $\begin{array}{l}-0.136^{* *} \\
(0.059)\end{array}$ & $\begin{array}{l}-0.120^{* *} \\
(0.052)\end{array}$ & $\begin{array}{l}-0.017 \\
(0.015)\end{array}$ \\
\hline Effort/Luck & $\begin{array}{l}-0.055 \\
(0.048)\end{array}$ & $\begin{array}{l}-0.040 \\
(0.048)\end{array}$ & $\begin{array}{l}-0.015 \\
(0.011)\end{array}$ & $\begin{array}{l}-0.071 \\
(0.074)\end{array}$ & $\begin{array}{l}-0.071 \\
(0.062)\end{array}$ & $\begin{array}{l}0.001 \\
(0.021)\end{array}$ \\
\hline Luck/Effort & $\begin{array}{l}-0.087 * * \\
(0.038)\end{array}$ & $\begin{array}{l}-0.076^{* *} \\
(0.037)\end{array}$ & $\begin{array}{l}-0.011 \\
(0.011)\end{array}$ & $\begin{array}{l}-0.123 * \\
(0.072)\end{array}$ & $\begin{array}{l}-0.102 \\
(0.063)\end{array}$ & $\begin{array}{l}-0.020 \\
(0.018)\end{array}$ \\
\hline Effort/Effort & $\begin{array}{l}-0.053 \\
(0.040)\end{array}$ & $\begin{array}{l}-0.042 \\
(0.039)\end{array}$ & $\begin{array}{l}-0.011 \\
(0.011)\end{array}$ & $\begin{array}{l}-0.065 \\
(0.072)\end{array}$ & $\begin{array}{l}-0.052 \\
(0.063)\end{array}$ & $\begin{array}{l}-0.013 \\
(0.017)\end{array}$ \\
\hline Period Trend & $\begin{array}{l}0.000 \\
(0.002)\end{array}$ & $\begin{array}{l}0.000 \\
(0.002)\end{array}$ & $\begin{array}{l}0.000 \\
(0.001)\end{array}$ & $\begin{array}{l}-0.003 \\
(0.003)\end{array}$ & $\begin{array}{l}-0.003 \\
(0.002)\end{array}$ & $\begin{array}{l}0.001 \\
(0.001)\end{array}$ \\
\hline Male & $\begin{array}{l}0.066^{* * *} \\
(0.025)\end{array}$ & $\begin{array}{l}0.059 * * \\
(0.024)\end{array}$ & $\begin{array}{l}0.008 \\
(0.007)\end{array}$ & $\begin{array}{l}0.019 \\
(0.043)\end{array}$ & $\begin{array}{l}0.003 \\
(0.027)\end{array}$ & $\begin{array}{l}0.017 \\
(0.026)\end{array}$ \\
\hline Rank & $\begin{array}{l}-0.004 \\
(0.006)\end{array}$ & $\begin{array}{l}-0.003 \\
(0.006)\end{array}$ & $\begin{array}{l}-0.001 \\
(0.001)\end{array}$ & $\begin{array}{l}-0.029 * * * \\
(0.010)\end{array}$ & $\begin{array}{l}-0.022 * * \\
(0.009)\end{array}$ & $\begin{array}{l}-0.006^{*} \\
(0.004)\end{array}$ \\
\hline Earnings in last round & $\begin{array}{l}0.000 \\
(0.000)\end{array}$ & $\begin{array}{l}-0.000 \\
(0.000)\end{array}$ & $\begin{array}{l}0.000 * \\
(0.000)\end{array}$ & $\begin{array}{l}-0.000 \\
(0.000)\end{array}$ & $\begin{array}{l}-0.000 \\
(0.000)\end{array}$ & $\begin{array}{l}0.000 \\
(0.000)\end{array}$ \\
\hline Attacked in last round & $\begin{array}{l}0.025 \\
(0.018)\end{array}$ & $\begin{array}{l}0.017 \\
(0.018)\end{array}$ & $\begin{array}{l}0.010 \\
(0.008)\end{array}$ & $\begin{array}{l}0.031 \\
(0.024)\end{array}$ & $\begin{array}{l}0.033 \\
(0.036)\end{array}$ & $\begin{array}{l}0.004 \\
(0.031)\end{array}$ \\
\hline Constant & $\begin{array}{l}0.084 \\
(0.068)\end{array}$ & $\begin{array}{l}0.085 \\
(0.069)\end{array}$ & $\begin{array}{l}0.002 \\
(0.018)\end{array}$ & $\begin{array}{l}0.268 * * * \\
(0.069)\end{array}$ & $\begin{array}{l}0.244 * * * \\
(0.068)\end{array}$ & $\begin{array}{l}0.020 \\
(0.028)\end{array}$ \\
\hline \multicolumn{7}{|l|}{ Panel B: Difference Estimates } \\
\hline Luck/Luck - Luck/Effort & $\begin{array}{l}0.061 * * \\
(0.030)\end{array}$ & $\begin{array}{l}0.056^{*} \\
(0.032)\end{array}$ & $\begin{array}{l}0.006 \\
(0.006)\end{array}$ & $\begin{array}{l}-0.013 \\
(0.038)\end{array}$ & $\begin{array}{l}-0.017 \\
(0.036)\end{array}$ & $\begin{array}{l}0.003 \\
(0.009)\end{array}$ \\
\hline Effort/Immobility - Effort/Luck & $\begin{array}{l}0.081 \\
(0.051)\end{array}$ & $\begin{array}{l}0.053 \\
(0.049)\end{array}$ & $\begin{array}{l}0.028 * * * \\
(0.009)\end{array}$ & $\begin{array}{l}0.084 \\
(0.067)\end{array}$ & $\begin{array}{l}0.024 \\
(0.043)\end{array}$ & $\begin{array}{l}0.059 \\
(0.047)\end{array}$ \\
\hline Effort/Immobility - Effort/Effort & $\begin{array}{l}0.080 * \\
(0.043)\end{array}$ & $\begin{array}{l}0.055 \\
(0.041)\end{array}$ & $\begin{array}{l}0.024 * * * \\
(0.009)\end{array}$ & $\begin{array}{l}0.079 \\
(0.063)\end{array}$ & $\begin{array}{l}0.005 \\
(0.044)\end{array}$ & $\begin{array}{l}0.073 * \\
(0.044)\end{array}$ \\
\hline Effort/Luck - Effort/Effort & $\begin{array}{l}-0.002 \\
(0.036)\end{array}$ & $\begin{array}{l}0.002 \\
(0.037)\end{array}$ & $\begin{array}{l}-0.004 \\
(0.004)\end{array}$ & $\begin{array}{l}-0.005 \\
(0.060)\end{array}$ & $\begin{array}{l}-0.019 \\
(0.051)\end{array}$ & $\begin{array}{l}0.013 \\
(0.014)\end{array}$ \\
\hline Observations & 2,000 & 2,000 & 2,000 & 1,700 & 1,700 & 1,700 \\
\hline No of Subjects & 200 & 200 & 200 & 170 & 170 & 170 \\
\hline
\end{tabular}

Note: Estimates from Random effects regressions with standard errors, clustered at the group level, in parentheses. The treatments are reported as a/b where a represents the method of initial 
endowment and $\mathrm{b}$ the mobility mechanism. Dependent Variable: $(1,4)$ Attacks directed towards player j; $(2,5)$ Attacks directed towards HI $(3,6)$ Attacks directed towards LI. Panel A presents coefficients of Random effects regressions. Panel B uses post-estimation linear combination tests of hypotheses using $t$-tests. The sample is restricted to periods $11-20$ of stage 2 . *** $p<$ $0.01, * * p<0.05, * p<0$. 


\section{Appendix A2}

Online survey questions:

\section{General attitudes towards income immobility:}

- Suppose that there is limited income mobility in your country. In this case, do you believe that limited income mobility could impact behavior?

\section{Initial income via luck:}

- Now suppose in your country a person's initial income status such as high or low income is assigned based on luck/chance but income mobility is limited, meaning moving up the income distribution is very unlikely. In this case, do you believe that limited income mobility could impact behavior?

\section{Initial Income via effort:}

- Now suppose in your country a person's initial income status such as high or low income is assigned based on effort/hard work but income mobility is limited, meaning moving up the income distribution is very unlikely. In this case, do you believe that limited income mobility could impact behavior?

\section{Mobility via effort}

- Now suppose that the only way to move up in the income distribution (that is, to improve one's self financially and get ahead in life) is by putting in effort/hard work, and income mobility exists, meaning moving up the income distribution is quite possible. In this case do you believe that mobility by effort/hard work could impact behavior relative to a setting where income mobility is limited? 


\section{Mobility via luck}

- Now suppose that the only way to move up in the income distribution (that is, to improve one's self financially and get ahead in life) is by luck/chance, and income mobility exists, meaning moving up the income distribution is quite possible. In this case do you believe that mobility by luck/chance could impact behavior relative to a setting where income mobility is limited? 